\title{
1 Exploring the tymovirids landscape through metatranscriptomics data
}

2 Nicolás Bejerman ${ }^{1,2}$, Humberto Debat ${ }^{1,2}$

3

$4 \quad{ }^{1}$ Instituto de Patología Vegetal - Centro de Investigaciones Agropecuarias - Instituto Nacional de

5 Tecnología Agropecuaria (IPAVE-CIAP-INTA), Camino 60 Cuadras Km 5,5 (X5020ICA), Córdoba,

6 Argentina

$7 \quad{ }^{2}$ Consejo Nacional de Investigaciones Científicas y Técnicas. Unidad de Fitopatología y Modelización

8 Agrícola, Camino 60 Cuadras Km 5,5 (X5020ICA), Córdoba, Argentina

9

10 Corresponding author: Nicolás Bejerman, bejerman.nicolas@inta.gob.ar 


\section{Abstract}

13 Tymovirales is an order of viruses with positive-sense, single-stranded RNA genomes that mostly infect

14 plants, but also fungi and insects. The number of tymovirid sequences has been growing in the last few

15 years with the extensive use of high-throughput sequencing platforms. Here we report the discovery of 31

16 novel tymovirid genomes associated with 27 different host plant species, which were hidden in public

17 databases. These viral sequences were identified through a homology searches in more than 3,000 plant

18 transcriptomes from the NCBI Sequence Read Archive (SRA) using known tymovirids sequences as

19 query. Identification, assembly and curation of raw SRA reads resulted in 29 viral genome sequences with

20 full-length coding regions, and two partial genomes. Highlights of the obtained sequences include viruses

21 with unique and novel genome organizations among known tymovirids. Phylogenetic analysis showed

22 that six of the novel viruses were related to alphaflexiviruses, seventeen to betaflexiviruses, two to

23 deltaflexiviruses and six to tymoviruses. These findings resulted in the most complete phylogeny of

24 tymovirids to date and shed new light on the phylogenetic relationships and evolutionary landscape of this

25 group of viruses. Furthermore, this study illustrates the complexity and diversity of tymovirids genomes

26 and demonstrates that analyzing SRA public data provides an invaluable tool to accelerate virus discovery

27 and refine virus taxonomy.

\section{Introduction}

30 The application of high-throughput sequencing (HTS) is becoming a fundamental tool in biomedical research, resulting in a steep increase in the number of genome and transcriptome sequencing projects that is leading to a massive number of nucleotides deposited in the Sequence Read Archive (SRA) of the National Center for Biotechnology Information (NCBI). Over 16,000 petabases $\left(10^{15}\right.$ bases) have been deposited in the SRA, with over 6,000 petabases available as open-access data [1], and this number is increasing significantly each year. This huge amount of data provides a significant challenge derived in the high costs of data storage and management. Given the nature, objectives and magnitude of the sequencing projects most of the generated data remains largely unexplored.

In the last years the application of metagenomics approaches resulted in the discovery of an abundant number of novel viruses. Most of them likely do not induce any apparent symptoms in their host or their host is unknown. In addition, the detection of multiple viruses in single samples suggest that mixed infections are common and represent an important constrain to an unbiased assessment of the contribution of each virus in a tentative pathosystem. Importantly, detections in metagenomics datasets usually correspond to novel and unreported viruses. This illustrates how limited is our knowledge about the richness of the plant virosphere, that seems to be exceedingly diverse in every host assessed so far [24]. Even though the application of HTS has resulted in the discovery of a great number of viruses, the pace of discovery suggest that it is still a minuscule portion of the whole virosphere, which has led to initiatives to accommodate this massive diversity in a proposal for a first comprehensive megataxonomy of the virus world [5].

49 The submitters of transcriptome datasets often limit their scientific interest to their specific field of study, 50 leaving behind a large amount of unused data which is potentially valuable [6]. Several studies in the last 51 few years have been focusing in the analysis of such transcriptome datasets, where viral sequences could 
52 be hidden in plain sight, which resulted in the discovery of novel viral sequences [7-13]. Simmonds and

53 colleagues [14] consensually stated that viruses that are known only from metagenomic data can, should,

54 and have been incorporated into the official classification scheme overseen by the International

55 Committee on Taxonomy of Viruses (ICTV). Therefore, analyzing public sequence databases is

56 becoming a great source for mining novel plant viruses, that results in the identification of novel viruses

57 in hosts with no previous record of virus infections [7]. The analysis of publically available databases

58 does not require the acquisition of samples and subsequent sequencing, resulting in an inexpensive and

59 sustainable approach for virus discovery. Proper attribution to the generators of the original data is

60 essential to promote the good practices of open and transparent research, which enable the production of

61 new results with existing data. Thus, the secondary analysis of publically available transcriptomic data to

62 address novel research question and objectives is likely a wide-ranging, efficient and cost-effective

63 approach for virus discovery due to the millions of datasets from a vast variety of potential host species

64 available at the NCBI-SRA [11].

65 Tymovirales is an order of viruses which encompass viruses with a positive-sense, single-stranded RNA

66 genome that mostly infect plants, but some are associated to fungi, while others are associated with

67 insects. This order is taxonomically classified into five families: Alphaflexiviridae, Betaflexiviridae,

68 Deltaflexiviridae, Gammaflexiviridae, whose members have flexuous filamentous virions, and

69 Tymoviridae, whose members have isometric virions [15].

70 The family Alphaflexiviridae contains seven genera: Allexivirus Lolavirus, Mandarivirus, Platypuvirus

71 and Potexvirus genera comprised by plant-associated viruses, while Botrexvirus and Sclerodarnavirus

72 genera correspond to fungi-associated viruses [16]. However, a recent proposal suggested to abolish the

73 genus Mandarivirus and create the subgenus Mandarivirus within the genus Potexvirus [17].

74 Alphaflexiviruses have a polyadenylated genome of 5.9-9.0 kb in size with 1 or 5 open reading frames

75 (ORFs) in those fungi-associated viruses and 5 to 7 ORFs in those plant-infecting viruses. The gene

76 encoding the replicase (REP) is the only conserved among all alphaflexivirues. In plant-infecting

77 alphafleviruses, the gene encoding the capsid protein (CP) and, with the exception of platypuviruses, the

78 module of the three overlapping ORFs 2 to 4, which encode the triple gene block (TGB) that is involved

79 in the cell-to-cell movement, are conserved [16].

80 The family Betaflexiviridae is composed by plant-infecting viruses, classified into two subfamilies,

81 Quinvirinae and Trivirinae, distinguished by the cell-to-cell type movement protein (MP), 30K-like or

82 TGB, that are classified in thirteen genera. Carlavirus, Foveavirus, and Robigovirus genera belong to the

83 Quinvirianae subfamily, while Capillovirus, Chordovirus, Citrivirus, Divavirus, Prunevirus, Ravavirus,

84 Tepovirus, Trichivirus, Tepovirus, and Wamavirus genera belong to the Trinvirinae subfamily [15].

85 Betaflexiviruses have a polyadenylated genome of 6.5-9.5 kb in size with 2 to 6 ORFs. Each

86 betaflexivirus typically codes for a REP, a MP, and a CP; while some viruses also code for a nucleic acid

87 binding protein (NABP) [15]. The viruses belonging to the subfamily Quinvirinae have 5 to 6 ORFs,

88 while those viruses in the subfamily Trivirinae have 2 to 5 ORFs [15]. Among viruses belonging to the

89 later subfamily there is variation in their genome organization. For instance, the MP encoded by

90 capilloviruses and divaviruses is nested within the ORF1, while that one of citriviruses and trichoviruses

91 overlap with the REP [15]. 
92

The family Deltaflexiviridae contains one genera, named as Deltaflexivirus, which is comprised by fungiassociated viruses [18-20]. Deltaflexiviruses have a polyadenylated genome of 8.1-8.3 kb in size with 4 to 5 ORFs. The gene encoding the replicase is the only one conserved among all deltaflexiviruses [18-20]. The family Tymoviridae contains three genera the Marafivirus and the Maculavirus, which have a 3' terminal poly (A) tail, and Tymovirus, whose genomes are not polyadenylated [21]. The genus Marafivirus is exclusively composed of plant-infecting viruses, but several tymoviruses have been associated to fungi or insects [22-24]. Tymoviruses have a genome of 6.0-7.5 kb in size with 1 to 4 ORFs, and the gene encoding the replicase is the only conserved among all tymoviruses [21]. In this study we queried the publically available plant transcriptome datasets in the transcriptome shotgun assembly (TSA) database and their corresponding SRA datasets hosted at NCBI and identified 31 novel tymovirids from 27 plant species, showing structural, functional and evolutionary cues to be classified in new and existing genera within the families Alphaflexiviridae, Betaflexiviridae, Deltaflexiviridae and Tymoviridae in the order Tymovirales. The discovery of these new viruses increase the knowledge of tymovirids and greatly expands the number of viruses associated to the order Tymovirales.

\section{Materials and methods}

Identification of tymovirid sequences from public plant transcriptome datasets

The amino acid sequences corresponding to the replicase proteins of several known viruses belonging to the order Tymovirales, such as Cnidium virus X (QVW10166), Fusarium graminearum deltaflexivirus 1 (ANS13830), alfalfa virus F (AWB13379), eggplant mosaic virus (P20126), apple stem grooving virus (QVX32671), Diuris virus A (AFV57238), fig fleck-associated virus 2 (AOF41056), Helenium virus S (QQX32728), and garlic yellow mosaic-associated virus (AZM69107), were used as query in tBlastn searches with parameters word size $=6$, expected threshold $=10$, and scoring matrix $=$ BLOSUM62, against the viridiplantae (taxid:33090) TSA database. The obtained hits were explored by hand and based on percentage identity $(<90 \%)$, query coverage $(>50 \%)$ and E-value $(>1 \mathrm{e}-5)$, shortlisted as likely corresponding to novel virus transcripts, which were further analyzed. Given the redundant nature of many retrieved hits, a step of contig clustering was implemented using the CD-hit suite with standard parameters available at http://weizhongli-lab.org/cdhit_suite/cgi-bin/index.cgi?cmd=cd-hit. In addition, the raw data corresponding to the SRA experiments associated with the different target NCBI Bioprojects (Table 1) was retrieved for further analyses.

\section{Sequence assembly and identification}

The nucleotide (nt) raw sequence reads from each analyzed SRA experiment linked to the TSA projects returning tymovirids-like hits were downloaded and pre-processed by trimming and filtering with the Trimmomatic tool as implemented in http://www.usadellab.org/cms/?page=trimmomatic, and the resulting reads were assembled de novo with Trinity release v2.11.00 using standard parameters. The transcripts obtained from de novo transcriptome assembly were subjected to bulk local BLASTX searches $\left(\right.$ E-value $<1 \mathrm{e}^{-5}$ ) against the TSA database obtained hits and a Refseq virus protein database available at ftp://ftp.ncbi.nlm.nih.gov/refseq/release/viral/viral.1.protein.faa.gz. The resulting viral sequence hits of each bioproject were visually explored. TSA and de novo assembled overlapping transcripts corresponding to tymovirids were re assembled and curated by mapping of SRA reads to the obtained 
132 sequences using Bowtie2 available at http://bowtie-bio.sourceforge.net/bowtie2/index.shtml, which was used to calculate total and mean coverage and reads per million (RPM) of each assembled virus sequence.

\section{Bioinformatics tools and analyses}

135 Sequence analyses

136 ORFs were predicted with ORFfinder (https://www.ncbi.nlm.nih.gov/orffinder/), functional domains and 137 architecture of translated gene products were determined using InterPro (https://www.ebi.ac.uk/interpro/search/sequence-search) and MOTIF search

139 (https://www.genome.jp/tools/motif/). Importin- $\alpha$ dependent nuclear localization signals were predicted 140 using cNLS Mapper available at http://nls-mapper.iab.keio.ac.jp/, and transmembrane domains were 141 predicted using the TMHMM version 2.0 tool (http://www.cbs.dtu.dk/services/TMHMM/).

\section{Percent identity matrices}

143 Percentage amino acid (aa) sequence identity of the predicted ORFs of each virus identified in this study 144 based on available tymovirids genome sequences were calculated using 145 https://www.ebi.ac.uk/Tools/psa/emboss_needle/.

146 Phylogenetic analysis

147 Phylogenetic analysis based on the predicted replicase and capsid protein of the tymovirids detailed in

148 Table S1, was done using MAFFT $7 \mathrm{https} / / /$ mafft.cbrc.jp/alignment/software with multiple aa sequence 149 alignments using FFT-NS-i as the best-fit model. The aligned aa sequences were used as input in MegaX software [25] to generate phylogenetic trees by the maximum-likelihood method using the best fit method which is detailed in the legend describing each phylogenetic tree. Local support values were computed using bootstrap with 1,000 replicates.

153 Recombination analysis

154 The sequences assembled in this study were examined for potential recombination events using the recombination detection program (RDP) version 5.05 with default settings [26]. Seven algorithms, BootScan, RDP, SiScan, GENECONV, MaxChi, Chimaera and Philpro were employed with a bonferroni corrected $P$ value cut-off of $<0.05$. An event was considered as positive if was identified by at least three or more algorithms.

\section{Results}

\section{Summary of discovered tymovirid sequences}

The complete coding regions of 29 novel tymovirids were identified, in addition, partial genomic sequences for two novel viruses were assembled. These viruses were associated with 27 plant host species (Table 1). Bioinformatic and source data of each of the 29 viral sequences, as well as the GenBank accession numbers and proposed classification are listed in Table 1; the summary of the assembly statistics of each virus of the tymovirid sequences identified from the transcriptome data available in the NCBI database are presented in Table S2. Based on phylogenetic relatedness, genome organization and sequence identity, the novel viruses were tentatively assigned to the established tymovirales families: Alphaflexiviridae, Betaflexiviridae, Deltaflexiviridae, and Tymoviridae. 10 herbaceous dicots, 8 herbaceous monocots, and 9 woody dicots plant were identified as putative hosts of the viruses described in this study. Most of the woody dicot plants (6/9) appeared to be infected by betaflexiviruses belonging 
172

173

174

175

176

177

178

179

180

181

182

183

184

185

186

187

188

189

190

191

192

193

194

195

196

197

198

199

200

201

202

203

204

205

206

207

208

209

210

211

to the Trivirinae subfamily (Table 1). The conserved domains of deduced proteins encoded by each tymovirid sequence were determined by predictive algorithms, and are shown in Table S3. Genomic architecture and evolutionary placement of the 29 discovered viruses are described below, grouped by affinity to members of the diverse families within the order Tymovirales.

\section{Alphaflexiviridae}

The complete coding region of six putative alphaflexiviruses, tentatively named Agave tequilana virus 2 (ATV2), Cymodocea nodosa virus 1 (CyNoV1), indian gooseberry virus 1 (InGoV1), ferula virus 1 (FerV1), peltate yam virus 1 (PelYV1) and Yucca gloriosa virus 1 (YuGlV1), were assembled in this study (Table 1). ATV2, InGoV1, FerV1, PelYV1 and YuGlV1 genomes have five ORFs in the order 5'Rep-TGB1-TGB2-TGB3-CP-3' (Fig.1A); while CyNoV1 genome has two ORFs in the order 5'-RepMP-3' (Fig. 1A), which is a distinctive genomic organization among plant alphaflexiviruses.

Blast P searches showed that ATV2, InGoV1, FerV1, PelYV1 and YuGlV1 ORFs 1, 2, 3, 4 and 5 encoded proteins are related with replicases, TGB1, TGB2, TGB3 and capsid proteins encoded by other potexviruses (Table 1); while the BlastP search of CyNoV1 ORF1 and ORF2 encoded proteins showed that are related with the replicase and the MP encoded by the alphaflexivirus donkey orchid symptomless virus (DOSV) (Table 1).

The viral methyltransferase, viral helicase and the RdRP motifs were identified in the replicases encoded by ATV2, CyNoV1, InGoV1, FerV1, PelYV1 and YuGlV1. The 3A/RNA2 MP family conserved domain was identified in the MP encoded by the CyNoV1. Whereas the conserved domains viral helicase, plant viral MP, triple gene block 3 and flexi_CP conserved domains were identified in the TGB1, TGB2, TGB3 and CP, respectively, encoded by ATV2, InGoV1, FerV1, PelYV1 and YuGlV1 (Table S3). Based on the ATV2, InGoV1, FerV1, PelYV1 and YuGlV1 aa sequences of the replicase and CP proteins, these viruses shared the highest sequence similarity with Vanilla virus X (VVX) (54.3\%) and Cassava virus X (CsVX) (46.6\%), Euonymus yellow mottle associated virus (EuYMaV) (58.6\%) and EuYMaV (52.5\%), Cnidium virus X (CnVX) (66.9\%) and VVX (57.7\%), Yam virus X (YVX) (57.8\%) and YVX (50.1\%), Potato virus X (PVX) (53.8\%) and Eu YMaV (47.2\%), respectively. While, the aa sequence of the CyNoV1 replicase shared the highest sequence similarity with DOSV (50.1\%). No recombination event was detected in the ATV2, CyNoV1, InGoV1, FerV1, PelYV1 and YuGIV1 genomic sequences.

In a phylogenetic tree based on the replicase aa sequence, PelYAV1 clustered together with the potexvirus ambrosia asymptomatic virus 1 , InGoV1 clustered together with the potexvirus EuYMaV and FerV1 clustered together with the potex virus CnVX, while ATV2 and YuGlV1 clustered together in a sister group to the potexviruses (Fig.2). Whereas, CyNoV1 clustered together with the platypuvirus DOSV (Fig.2). In the phylogenetric tree based on the $\mathrm{CP}$ aa sequences the same clustering were observed for ATV2, InGoV1, FerV1, PelYV1 and YuGlV1 (Figure S1).

\section{Betaflexiviridae}

The complete coding region of 15 putative betaflexiviruses, tentatively named as avocado virus 1 (AvoV1), avocado virus 2 (AvoV2), breadfruit virus 1 (BreFV1), Corylus avellana virus 1 (CorAvV1), Daiswa yunannensis virus 1 (DaYuV1), Gymnadenia rhellicani (GymRhV1), korean chestnut virus 1 
(KoChV1), Melampyrum roseum virus 2 (MelRoV2), Quercus castanea virus 1 (QueCaV1), Rhodiola rosea virus 1 (RhRoV1), Rhododendron delavayi virus 2 (RhoDeV2), Silene dioica virus 1 (SiDiV1), Suaeda fruticose virus 1 (SuFruV1), sweetleaf virus 1 (SLeV1) and Tagetes erecta virus 2 (TaEV2), well as the partial genome of two other betaflexiviruses, named Cymodocea nodosa virus (CyNoV2) and German iris virus 2 (GerIV1), were assembled in this study (Table 1). BreFV1, CorAvV1, GerIV1, KoChV1, QueCaV1, RhRoV1, SiDiV1 and SuFruV1 genomes have two ORFs, named as PolyproteinMP, where the ORF encoding the MP is overlapped (Fig.1B). GymRhV1 and MelRoV2 genomes have three ORFs in the order 5'- Polyprotein-MP-NABP-3' where the ORF encoding the MP is overlapped (Fig.1B). AvoV2 and DaYuV1 genomes have three ORFs in the order 5'-Rep-MP-CP-3' (Fig.1B), while RhoDeV2 has three ORFs in the order 5'-Rep-P2-P3-3' (Fig.1B). AvoV1 genome has five ORFs in the order 5'-Rep-MP-CP-P4-NABP-3' (Fig.1B). CyNoV2 genome has five ORFs in the order 5'-Rep-TGB1TGB2-TGB3-CP-3' (Fig.1B); while SleV1 and TaEV2 genome have six ORFs in the order 5'-RepTGB1-TGB2-TGB3-CP-NABP-3' (Fig. 1B).

Blast P searches showed that BreFV1, CorAvV1, GerIV1, GymRhV1, KoChV1, MelRoV2, QueCaV1, RhRoV1, SiDiV1 and SuFruV1 ORFs 1 and 2 encoded proteins are similar to the polyprotein and movement proteins of other divaviruses, capilloviruses and unclassified betaflexiviruses (Table 1), while the GymRhV1 and MelRoV2 ORF3 showed identity with the NABPs of trichoviruses (Table 1). Blast P searches showed that AvoV2 and DaYuV1 ORFs 1, 2 and 3 encoded proteins are similar to the replicases, movement proteins and capsid proteins of other betaflexiviruses (Table 1); while Blast P searches showed that RhoDeV2 ORF1 encoded protein is more similar to the replicase of other trichoviruses, but no hits were found when ORFs 2 and 3 encoded proteins were searched (Table 1). Blast P searches showed that AvoV1 ORFs 1, 2, 3 and 5 encoded proteins are similar to the replicases, movement proteins, capsid proteins and nucleic acid binding proteins of other betaflexiviruses, whereas no hits were found when AvoV1 ORF4 encoded protein was subjected to a BlastP search (Table 1). Blast P searches showed that CyNoV2 ORFs 1, 2, 3, 4 and 5 encoded proteins are similar to the replicases, TGB1, TGB2, TGB3 and capsid proteins of other foveaviruses (for CyNoV2) (Table 1). BlastP searches showed that SleV1 and TaEV2 ORFs 1, 2, 3, 4, 5 and 6 encoded proteins are similar to the replicases, TGB1, TGB2, TGB3, capsid proteins and nucleic acid binding proteins of other carlaviruses (Table 1).

The viral methyltransferase, viral helicase and the RdRP motifs were identified in the replicases encoded by Avo1, Avo2, RhoDeV2, SLeV1 and TaEV2, and in the polyproteins encoded by BreFV1, CorAvV1, DaYuV1, GymRhV1, KoChV1, MelRoV2, QueCaV1, RhRoV1, SiDiV1 and SuFruV1. The viral methyltransferase motif was not found in the CyNoV2 encoded replicase and GerIV1 encoded polyprotein, probably because they were only partially assembled and its $\mathrm{N}$-terminal region is missing, but the viral helicase and RdRP motifs were identified. Furthermore, the carlavirus endopeptidase conserved domain was found in the replicases encoded by SLeV1 and TaEV2. Whereas the trichovirus coat protein motif was found in the polyprotein encoded by BreFV1, CorAvV1, GerIV1, GymRhV1, KoChV1, MelRoV2, QueCaV1, RhRoV1, SiDiV1 and SuFruV1 and in the CP encoded by AvoV1, AvoV2 and DaYuV1; while the DUF1717 conserved domain was identified in the polyprotein encoded by BreFV1, CorAvV1, GerIV1, RhRoV1 and SiDiV1 and the 2OG-FeII_Oxy_2 motif was identified in the replicase encoded by AvoV2 and RhoDeV2. Moreover, the conserved domain viral MP was identified 
in the MP encoded by AvoV1, AvoV2, BreFV1, CorAvV1, DaYuV1 GerIV1, GymRhV1, KoChV1,

MelRoV2, QueCaV1, RhRoV1, SiDiV1 and SuFruV1. Whereas the conserved domains viral helicase, plant viral MP, triple gene block 3 and flexi_CP conserved domains were identified in the TGB1, TGB2, TGB3 and CP, respectively, encoded by CyNoV2, SleV1 and TaEV2. Furthermore, the Carlavirus coat motif was identified in the CP encoded by SLeV1 and TaEV2, and the carlavirus putative NABP conserved domain was identified in the NABP encoded by AvoV1, SLeV1 and TaEV2 (Table S3), while a viral_NABP conserved domain was identified in the NABP encoded by GymRhV1 and MelRoV2 (Table S3). No conserved domains were identified in the proteins 2 and 3 encoded by RhoDeV2, and in the protein 4 encoded by AvoV1 (Table S3), but a bipartite NLS was detected in the P3 encoded by RhoDeV2 and in the P4 encoded by AvoV1.

Based on the AvoV1, AvoV2, CyNoV2, DaYuV1, SleV1 and TaEV2 aa sequences of the replicase and $\mathrm{CP}$ proteins, these viruses shared the highest sequence similarity with grapevine Kizil Sapak virus (GKSV) (50.1\%) and fig latent virus 1 (FLV1) (48.6\%), citrus leaf blotch virus (CLBV) (55.6\%), and Camellia ringspot-associated virus 2 (CRSaV2) (52.8\%), Asian prunus virus 3 (APV3) (43.0\%), and Grapevine rupestris stem pitting-associated virus (GRSPaV) (44.7\%), Agapanthus virus A (AgVA) (54.4\%) and AgVA (51.7\%), Helenium virus S (HelVS) (60.6\%) and HelVS (63.9\%), HelVS (60.9\%) and (HelVs) (65.7\%), respectively. Whereas the aa sequence of the BreFV1, CorAvV1, GerIV1, GymRhV1, KoChV1, MelRoV2, QueCaV1, RhRoV1, RhoDeV2, SiDiV1 and SuFruV1 replicase protein, shared the highest sequence similarity with Apple stem grooving virus (ASGV) (69.4\%), ASGV (58.8\%), ASGV (53.6\%), diuris virus B (DiVB) (52.2\%), diuris virus A (DiVA) (53.5\%), DiVB (47.7\%), DiVB (52.7\%), Hobart betaflexivirus 1 (HoBFV1) (47.1\%), cherry mottle leaf virus (CMLV) (44.1\%), ASGV (49.7\%) and Camellia ringspot-associated virus 3 (CRSaV3) (52.8\%), respectively.

274 No recombination event was detected in the betaflexiviruses assembled in this study.

275 In a phylogenetic tree based on the replicase aa sequence of viruses belonging to the subfamily

276 Quinvirinae, SleV1 and TaEV2 clustered together and this group was related with the carlavirus HelVS.

277 On the other hand, CyNoV2 formed a monophyletic group that was grouped with the unclassified betaflexiviruses yam virus Y and sugarcane striate mosaic-associated virus (Fig. 3). Whereas, in the phylogenetic tree based on the $\mathrm{CP}$ aa sequence, SleV1 and TaEV2 clustered together and this group was related with the carlavirus HelVS; while CyNoV2 clustered together with the foveavirus rubus virus 1 (Figure S2).

282 In a phylogenetic tree based on the replicase aa sequence of viruses belonging to the subfamily

283 Trinvirinae, AvoV1 was placed is the same clade as GKSV and FLV1, that is separated from the clades

284 formed by other genera belonging to the Trinvirinae subfamily (Fig.4). RhoDeV2 formed a monophyletic cluster that is related with the Chordovirus clade and the ravavirus Ribes americanum virus A (Fig. 4). GymRhV1 clustered together with MelRoV2, and KoChV1 with QueCaV1 and this two clades were grouped with the Divavirus clade (Fig. 4). AvoV2 formed a monophyletic cluster that is related with the Citrivirus clade and the unclassified betaflexivirus citrus yellow spot virus (Fig. 4). DaYuV1 clustered together with $\mathrm{AgVA}$ and this cluster is separated from the clades formed by members of other genera belonging to the Trinvirinae subfamily (Fig. 4). SuFruV1 clustered together with CRSaV3 and this clade 
292 cluster grouped with capilloviruses (Fig. 4). Whereas, BreFV1, CorAvV1 and GerIV1 clustered with the capilloviruses ASGV and yacon virus A (Fig. 4). In the phylogenetic tree based on the CP aa sequence,

294 AvoV1 was placed in the same clade as GKSV and FLV1 (Figure S3). GymRhV1 clustered together with

295 MelRoV2, and KoChV1 with QueCaV1 and this two clades were grouped with the Divavirus clade

296 (Figure S3). AvoV2 formed a monophyletic cluster that is related with the Prunevirus clade (Supp. Figure

297 3). DaYuV1 clustered together with AgVA (Figure S3). SuFruV1 is related with CRSaV3 and

298 capilloviruses (Figure S3). RhRoV1 clustered together with HoBFV1 and SiDiV1 and this cluster

299 grouped with known capilloviruses, while, CorAvV1 and GerIV1 clustered with the capilloviruses yacon

300 virus A and BreFV1 with the capillovirus ASGV (Figure S3).

\section{Deltaflexiviridae}

302 The complete coding region of two putative deltaflexiviruses, tentatively named Agave tequilana virus 3

303 (ATV3) and sesame virus 1 (SesV1), were assembled in this study (Table 1). ATV3 and SesV1 genomes 304 consist of five ORFs in the order 5'Rep-P2-P3-P4-P5-3' (Fig.1C).

305 Blast P searches showed that ATV3 and SesV1 ORF1 encoded proteins are similar to the replicases of 306 other deltaflexiviruses (Table 1); while BlastP searches showed SesV1 ORFs 4 and 5 are similar to the P4 307 and P5 proteins of other deltaflexiviruses (Table 1). No hits were found when ATV3 ORFs 2, 3, 4 and 5 encoded proteins, as well as SesV1 ORFs 2, 3 encoded proteins, were subjected to a BlastP search (Table 309 1).

310 The typical viral methyltransferase and the RdRP motifs were identified in the replicase encoded by 311 ATV3, and these two conserved domains as well a viral helicase conserved domain was identified in the 312 SesV1 encoded replicase; while no conserved domains were identified in the other proteins encoded by 313 ATV3 and SesV1 (Table S3).

314 Based on the ATV3 and SesV1 aa sequences of the replicase, these viruses shared the highest sequence 315 similarity with Fusarium graminearum deltaflexivirus 1 (FgDFV1) (55.7\%) and FgDFV1 (58.2\%), 316 respectively.

317 No recombination event was detected in the deltaflexiviruses assembled in this study.

318 In a phylogenetic tree based on the replicase aa sequence, ATV3 and SesV1 were grouped with other

319 known deltaflexiviruses (Fig.5).

320 Tymoviridae and tymo-like virus

321 The complete coding region of six putative tymoviruses, tentatively named Davidia involucrata virus 1

322 (DaInvV1), Davidia involucrata virus 2 (DaInvV2), kava virus 1 (KaV1), polish wheat virus 1 (PolWh1), 323 watercress associated virus $1(\mathrm{WaCraV1})$ and yellow poplar virus 1 (YePoV1) were assembled in this 324 study (Table 1). DaInv1 and DaInv2 genomes have one ORF (Fig.1D), YePoV1 has two ORFs in the 325 order 5'Rep-CP-3' (Fig.1D); while KaV1 and PolWhV1 genomes have three ORFs in the order 5'-Rep326 P2-P3-3', while WaCraV1 genome has three ORFs in the order 5'-Rep-CP-P3-3' (Fig. 1D).

327 Blast $\mathrm{P}$ searches showed that DaInv1 and DaInv2 ORF encoded protein are similar to the polyprotein of 328 other marafiviruses (Table 1). Blast P searches showed that KaV1, PolWhV1, WaCraV1 and

329 YePoV1ORF1 encoded proteins are similar to the replicases of other tymo-like viruses, while WaCraV1 330 and YePoV1 ORF 2 encoded proteins are similar to the CP of other tymo-like viruses, and WaCraV1 331 ORF3 encoded protein is similar to the P3 encoded by other tymo-like viruses (Table 1). No hits were 
332 found when KaV1, PolWhV1 and WaCraV1 ORFs 2 and 3 encoded proteins were subjected to a BlastP

333 search (Table 1).

334 The viral methyltransferase, viral helicase and the RdRP motifs were identified in the DaInV1 and

335 DaInv2 polyproteins and in the replicase encoded by KaV1, PolWhV1, WaCraV1 and YePoV1, while the

336 tymovirus endopeptidase conserved domain was identified in the DaInV1 and DaInv2 polyproteins and in

337 the replicase encoded by PolWhV1 and WaCraV1. Whereas the tymovirus coat protein conserved domain

338 was identified in the DaInV1 and DaInv2 polyproteins and in the capsid protein encoded by WaCraV1

339 (Table S3). Moreover, a transmembrane domain was identified in the protein 2 and protein 3 encoded by

$340 \mathrm{KaV1}$ and WaCraV1, respectively.

341 Based on the nearly complete assembled genomes of DaInv1, DaInv2, KaV1, PolWhV1, WaCraV1 and

342 YePoV1, these viruses shared the highest sequence similarity with Medicago sativa marafivirus 1

343 (MsMV1) (57.2\%), citrus sudden death-associated virus (CSDaV) (59.1\%), Ullucus tymovirus 1

344 (UTyV1) (42.3\%), Fusarium graminearum mycotymovirus 1 (FgMTV1) (51.6\%), bee macula-like virus 2

345 (BeeMLV2) (55.2\%) and prunus yellow spot-associated virus (PYSaV) (59.7\%), respectively. While the

346 DaInv1, DaInv2, WaCraV1 and YePoV1 CP shared the highest amino acid sequence identity with

347 MsMV1 (57.36\%), CSDaV (59.09\%), BeeMLV2 (48.70\%) and PYSaV (44.94\%)

348 No recombination events were detected in the DaInV1, DaInV2, KaV1, PolWhV1, WaCraV1 and

349 YePoV1 genomic sequences.

350 In a phylogenetic tree based on the replicase aa sequence, DaINV1 and DaINV2 clustered with

351 marafiviruses. DaINV1 was related to two clades, one formed by Medicago sativa marafivirus 1 and

352 alfalfa virus $\mathrm{F}$, and the other by citrus virus $\mathrm{C}$ and grapevine red globe virus; while DaInv2 was closely

353 related with blackberry virus S (Fig.6). WaCraV1 clustered together with the maculaviruses BeeMLV2

354 and Bombyx mori macula-like virus. KaV1 formed a monophyletic cluster that was distantly related with

355 known tymoviruses, while PolWhV1 clustered together with the mycotymoviruses FgMTV1 and this

356 viruses grouped with the cluster formed by the mycotymoviruses Sclerotinia sclerotorium mycotymovirus

357 1, Sclerotinia sclerotorium mycotymovirus 2 and Botrytis cinerea mycotymovirus 1 (Fig.6). Whereas,

358 YePoV1 clustered together with the tymo-like viruses PYSaV and grapevine associated tymo-like virus

359 (GaTLV) (Fig.6).

\section{Discussion}

361 In the last few years, the employment of HTS, allowed the identification and characterization of several

362 novel viruses associated to the order Tymovirales, which may be asymptomatic [27-33]. Moreover, some

363 tymovirids were also discovered mining publically available transcriptome datasets at the NCBI [34-40].

364 Thus, many tymovirales-like sequences could be hidden in publicly available plant transcriptome

365 datasets. Therefore, we conducted an extensive search of tymovirales-like sequences querying the

366 transcriptome shotgun assembly (TSA) which resulted in the identification of 31 novel tymovirids. After

367 extensive structural and functional annotation and evolutionary analyses we suggest these viruses

368 correspond to potential new members of new virus species, which expand the diversity of the complete

369 Tymovirales order by ca. $30 \%$.

370 Conserved domains 
371 All the replicase proteins assembled in this study contained the methyltransferase (MTR), RNA helicase

372 (Hel), and RNA-dependent RNA polymerase (RdRp) domains. These domains have been identified in a

373 wide range of ssRNA viruses, where MTR is involved in capping, which enhances mRNA stability [41],

374 the RdRp corresponds to the main viral replicase, an essential protein encoded in all RNA viruses, while

375 the HEL domain plays multiple roles at different stages of viral RNA replication [42].

376 Transmembrane domains were identified in the TGB2 and TGB3 proteins encoded by ATV2, CyNoV2,

377 FerV1, InGoV1, PelYV1, SLeV1, TaEV2 and YuGlV1, which also were reported for the TGB2 and

378 TGB3 proteins encoded by other foveaviruses, carlaviruses, potexviruses, robigoviruses and allexiviruses

379 [43], thus supporting the membrane-association and involvement in viral movement of these two proteins

380 [44-46].

381 Genome organization and phylogenetic relationships of the novel tymovirids

382 Alphaflexiviridae

383 ATV2, InGoV1, FerV1, PelYV1 and YuGlV1 showed a genomic organization 5'-Rep-TGB1-TGB2-

384 TGB3-CP-3', that is typical of potexviruses [16] and these five viruses are phylogenetically related with

385 other potexviruses, but the highest nt identities when the Rep and CP genes were compared with other

386 potexviruses was below $72 \%$, which is the criteria to demarcate species in the Alphaflexiviridae family

387 [16]. Thus, based on sequence similarities, genomic organization and phylogenetic relationships, ATV2,

388 InGoV1, FerV1, PelYV1 and YuGlV1 should be classified as new members of the genus Potexvirus in

389 the family Alphaflexiviridae.

390 On the other hand, CyNoV1 has a distinctive genomic organization among alphaflexiviruses because only

391 two ORFs, encoding a replicase and MP, were identified in its genome, likely being the first

392 alphaflexivirus reported so far that has only two ORFs. Like the sclerodarnaviruses, CyNoV1 does not

393 encode a putative CP. Moreover, its replicase and MP are distantly related with that one encoded by the

394 platypuvirus DOSV. Similarly to the DOSV MP, the CyNoV1 encoded MP is related with the 3A-like

395 MPs of viruses belonging to the families Tombusviridae and Virgaviridae [47], which is distinctive

396 among alphaflexiviruses, where the TGB proteins are the MPs [16]. Despite that the replicase nt sequence

397 similarity between CyNoV1 and DOSV is above the $45 \%$ threshold value to demarcate genus in the

398 family Alphaflexiviridae [16], and that the Rep of these two viruses grouped together in the phylogenetic

399 tree, CyNoV1 has a genomic organization different than that one reported for DOSV [47]; thus CyNoV1

400 could be classified as a member of a novel genus belonging to the family Alphaflexiviridae.

\section{Betaflexiviridae}

402 SleV1 and TaEV2 showed a genomic organization 5'-Rep-TGB1-TGB2-TGB3-CP-NABP-3', that is

403 typical of carlaviruses [15]. Moreover, these two viruses are phylogenetically related with other

404 carlaviruses, but the highest nt identities when the Rep and CP genes were compared with other

405 carlaviruses was well below 72\%, which is the criteria to demarcate species in the Betaflexivirus family

406 [15]. Thus, based on sequence similarities, genomic organization and phylogenetic relationships, SleV1

407 and TaEV2 should be classified as novel members of the genus Carlavirus in the family Betaflexiviridae.

408 BreFV1, CorAvV1, GerIV1, RhRoV1, SiDiV1 and SuFruV1 showed a genomic organization with two

409 overlapping ORFs; where one encodes a Rep protein fused to the CP, while the other encodes a MP,

410 which is typical of capilloviruses [30]. The highest nt identity when the Rep and CP proteins were 
411 compared with other betaflexiviruses was below $72 \%$, which is the criteria to demarcate species in the

412 Betaflexiviridae family [15]. The BreFV1, CorAvV1, GerIV1, RhRoV1, SiDiV1 Rep and CP clustered

413 together with known capilloviruses, while SuFruV1 Rep and CP was similar to the one of CRSaV3 and

414 these two viruses are related with known capilloviruses. Interestingly, the CRSaV3 genomic organization

415 is different than the one of SuFruV1 and known capilloviruses [48]. Moreover, the conserved domain

416 DUF1717 was identified in the polyprotein of BreFV1, CorAvV1, GerIV1, RhRoV1 and SiDiV1, but not

417 in the SuFruV1 polyprotein. The DUF1717 domain, which function is unknown, was found in the

418 polyprotein of the capilloviruses ASGV and cherry virus A [49, 50] as well as in the polyprotein of the

419 unclassified betaflexivirus HoBFV1; however this domain was not found in the polyprotein encoded by

420 CRSaV3. Sequence similarities, genomic organization and phylogenetic relationships supports that

421 BreFV1, CorAvV1, GerIV1 RhRoV1, SiDiV1, and SuFruV1 as well as the previously reported HoBFV1

422 (Roberts et al., 2018) and CRSaV3 [48] should be classified as members of the genus Capillovirus in the

423 family Betaflexiviridae, where CRSaV3 would be the first capillovirus with three ORFs instead of two,

424 while HoBFV1 is likely the first insect-associated capillovirus described so far.

425 KoChV1 and QueCaV1 genomes have two overlapping ORFs, one is the fused Rep-CP ORF and the

426 other one encodes the MP, which is typical of divaviruses [34]; while GymRhV1 and MelRoV2 also have

427 a third ORF which encodes a putative NABP. These four viruses were distantly related with other

428 divaviruses, and the highest nt identity when the Rep and CP genes were compared with other

429 betaflexiviruses was below $72 \%$, which is the criteria to demarcate species in the Betaflexiviridae family

430 [15]. Moreover, these viruses clustered together with divaviruses both in the Rep and CP phylogenetic

431 trees, thus they likely share a similar evolutionary history. Thus, based on sequence similarities, genomic

432 organization and phylogenetic relationships, KoChV1 and QueCaV1 should be classified as novel

433 members of the genus Divavirus in the family Betaflexiviridae. Despite that GymRhV1 and MelRoV2

434 have a different genomic organization than known divaviruses, based on sequence similarities and

435 phylogenetic relationships these two viruses should also be classified as novel members of the genus

436 Divavirus. The genus Trichovirus also contains viruses that display different genomic organizations [15],

437 which support the potential classification of GymRhV1 and MelRoV2 as divaviruses.

438 The genomic organization of AvoV1 5'-Rep-MP-CP-P4-NABP-3', is similar to that reported for the

439 betaflexivirus GKSV [52]. The highest nt identity when the Rep and CP proteins were compared with

440 other betaflexiviruses was below $72 \%$, which is the criteria to demarcate species in the Betaflexiviridae

441 family [15]. Neither conserved domains were identified, nor any BlastP hits were obtained when the

442 AvoV1 ORF4 encoded protein was analyzed, which is similar to that reported for the encoded protein by

443 the GKSV ORF4 [52]. Interestingly, in this protein of unknown function, a NLS was found in the one

444 encoded by AvoV1, but no NLS was detected in the protein encoded by GKSV ORF4. Further studies

445 should be conducted to characterize the putative function of this protein. AvoV1 and GKSV, along with

446 FLV1, which full sequence has not been obtained yet [53], were phylogenetically related in a distinct

447 clade from other genera belonging to the subfamily Trivirinae. GKSV and FLV1 were proposed to belong

448 to a new genus named as Fivivirus [52]. Based on sequence similarities, genomic organization and

449 phylogenetic relationships, AvoV1 should be classified as novel member of this genus, which name could

450 be changed to Avofivivirus (derived from Avocado-Ficus-Vitis-virus). 
451 CyNoV2 genome organization 5'-Rep-TGB1-TGB2-TGB3-CP-3', resembles the one described both for

452 foveaviruses [54] and for the unclassified betaflexiviruses banana mild mosaic virus [55], sugarcane

453 striate mosaic-associated virus [56] and yam virus $\mathrm{Y}$ [57]. The identities between the nt sequence of the

454 replicase and $\mathrm{CP}$ of CyNoV2 with other betaflexiviruses is below 45\%, that is the genus demarcation

455 criteria for betaflexiviruses [15]. CyNoV2 replicase clustered together with the unassigned

456 betaflexiviruses sugarcane striate mosaic-associated virus and yam virus $\mathrm{X}$, while its $\mathrm{CP}$ was

457 phylogenetically related with known foveaviruses. Based on sequence similarities, and the incongruences

458 in the phylogenetic relationships observed between Rep and CP proteins, which likely indicates a distinct

459 evolutionary history of CyNoV2 Rep and CP, this virus may represents a novel member of a new genus

460 within the Quinvirinae subfamily in the Betaflexiviridae family, which could be tentatively named as

461 Cynovirus.

462 The AvoV2 genome has three ORFs with a genomic organization 5'-Rep-MP-CP-3', that is similar to that

463 reported for the unclassified betaflexvirus citrus yellow spot virus [58], almost identical to that of

464 citriviruses, where the ORF that encodes the MP is located adjacent to the ORF that encodes the Rep

465 protein [15]. However, in the AvoV2 genomes, the ORF encoding the CP is overlapped with that one

466 encoding the MP [58]; while in the citriviruses these two ORFs are separated by an intergenic region [15,

$46732,59]$. Similarly to the AvoV2 genome, in the pruneviruses the ORFs encoding the MP and CP are

468 overlapped [15]; however most of the pruneviruses have four ORFs instead of three [48]. AvoV2 Rep and

$469 \mathrm{CP}$ were distantly related with other citrivirus and pruneviruses, respectively, and the replicase and CP nt

470 sequence similarity is above the $45 \%$ threshold value to demarcate genus in the family Betaflexiviridae

471 [15]. However, this virus formed a monophyletic cluster that was related with citrus yellow spot and the

472 Citrivirus clade, and the Prunevirus clade when the Rep and CP proteins were analyzed, respectively.

473 Therefore, there is incongruences in the phylogenetic relationships observed between Rep and CP

474 proteins, which likely indicates a distinct evolutionary history of AvoV2 Rep and CP. Thus, based on its

475 genomic organization and phylogenetic relationships, AvoV2 should be classified as a novel member of a

476 new genus within the subfamily Trivirinae in the family Betaflexiviridae, which could be tentatively

477 named as Avovirus.

478 It is tempting to speculate that the discrepancy regarding phylogenetic tree topology between the one

479 inferred from the Rep sequences and the one inferred from the CP sequences found for CyNoV2 and

480 Avo2 could be linked to ancestral recombination events, or that these genes have different mutation rates.

481 Similar hypotheses were speculated for other betaflexiviruses where discrepancies on the REP and CP

482 evolutionary relationships have also been observed [58, 60].

483 The DaYuV1 genome has three ORFs, with a genomic organization 5'-Rep-MP-CP-3', that is similar to

484 the unclassified betaflexivirus $\mathrm{AgVA}$, and reminiscent to the one reported for those trichoviruses with

485 three ORFs, where the ORF that encodes the MP is slightly overlapped with the ORF that encodes the

486 Rep [15]. However, in the DaYuV1 and AgVA genomes the ORF encoding the CP is separated from the

487 ORF encoding the MP by a short intergenic region, while in the trichoviruses, these two ORFs are

488 slightly overlapped [15, 61, 62]. DaYuV1 is distantly related with AgVA, and their replicase and CP nt

489 sequence similarity is below the $72 \%$ threshold value to demarcate species in the family Betaflexiviridae

490 [15]. DaYuV1 and AgVA Rep and CP proteins were phylogenetically related in a distinct clade from 
491 other viruses belonging to genera within the subfamily Trivirinae. Thus, based on sequence similarities, genomic organization and phylogenetic relationships, DaYuV1 and AgVA should be classified as novel members of a new genus within the subfamily Trivirinae in the family Betaflexiviridae, which could be tentatively named as Daisagavirus.

495 The RhoDeV2 genome has three ORFs, with a genomic organization 5'-Rep-P2-P3-3', that is similar to

496 the one reported for the carrot chordoviruses [63]. Its replicase is distantly related with the one encoded

497 by other betaflexiviruses, and the nt sequence similarity is below the $45 \%$ threshold value to demarcate

498 genus in the family Betaflexiviridae [15]. Neither hits were obtained nor conserved domains were

499 identified when the proteins encoded by ORFs 2 and 3 were analyzed, but a bipartite NLS was detected in

500 the sequence of the ORF 3 encoded protein. Thus, RhoDeV2 ORF2 and ORF3 encoded proteins have an

501 unknown function and are not likely a MP and CP, which are the putative proteins encoded by carrot

502 chordoviruses ORFs2 and 3 [63], which likely indicate that RhoDeV2 is unique among betaflexiviruses.

503 The RhoDeV2 replicase formed a monophyletic cluster that was related with the Chordovirus and

504 Ravavirus clades. Thus, sequence similarities, the evolutionary relationships with other betaflexiviruses

505 and the unknown function of its putative P2 and P3 proteins suggest that RhoDeV2 is a unique novel

506 betaflexivirus that should belong to a novel genus within the subfamily Trivirinae in the family

507 Betaflexiviridae, which could be tentatively named as Rhodovirus.

\section{Deltaflexiviridae}

509 The ATV3 and SesV1 genomic organization5'Rep-P2-P3-P4-P5-3', resembles the one described for the 510 deltaflexiviruses FgDFV1 [18]. Their replicase is distantly related with the one encoded by other 511 deltaflexiviruses, and phylogenetic analysis showed that ATV3 and SesV1 grouped together with the 512 deltaflexiviruses. Thus, based on sequence similarities, genomic organization and phylogenetic 513 relationships, ATV3 and SesV1 should be classified as novel members of the genus Deltaflexivrus in the 514 family Deltaxiviridae.

\section{Recombination}

516 Interestingly, despite that the recombination is a key process that strongly impact the evolution of many 517 plant virus species [26] and has been mentioned as a driving force in the evolution of flexiviruses [64], no 518 recombination event, using as threshold a p-value $<0.05$ in at least three algorithms, was detected in the 519 alphaflexiviruses, betaflexiviruses and deltaflexiviruses identified in this study.

\section{Tymoviridae and tymo-like virus}

521 DaInvV1 and DaInv2 genome organization resemble the one described for marafiviruses [65], and these

522 viruses are phylogenetically related with other marafiviruses. The highest aa identity when their CP was

523 compared with other marafiviruses was below $80 \%$, which is the criteria to demarcate species in the

524 Tymoviridae family [21].Thus, based on sequence similarities, genomic organization and phylogenetic

525 relationships, DaInvV1 and DaInv2 should be classified as novel members of the genus Marafivirus in

526 the family Tymoviridae.

527 YePoV1 genomic organization 5'Rep-CP-3', resembles the one reported for the tymovirids PYSaV [66]

528 and GaTLV [67]. YePoV1 grouped together with these two viruses in the phylogenetic tree, and their CP

529 shared an aa identity below $80 \%$, which is the threshold value to demarcate species in the Tymoviridae

530 family [21]. Thus, based on sequence similarities, genomic organization and phylogenetic relationships, 
531 YePoV1 would be the third member of the recently proposed genus Gratylivirus, that belongs to an

532 unassigned family within the order Tymovirales [66, 67].

533 WaCraV1 has three ORFs and its genomic organization 5'-Rep-CP-P3-3', is similar to the one reported

534 for the invertebrate-associated macula-like viruses BeeMLV2 [68] and Bombyx mori Macula like-virus

535 (BmMLV) [69], which differs from the one reported for the plant-associated maculaviruses [70, 71].

536 Interestingly, the P3 encoded by the WaCraV1 genome has a transmembrane domain, while no

537 transmembrane domains were identified in the P3 encoded by BeeMLV2 and BmMLV genomes; thus the

538 function of WaCraV1 P3 protein could be different than the BeeMLV2 and BmMLV P3s. WaCraV1

539 grouped together with BeeMLV2 and BmMLV in the phylogenetic tree, but their CP shared an aa identity

540 lower than $80 \%$, which is the criteria to demarcate species in the Tymoviridae family [21]. Phylogenetic

541 relationships suggest that $\mathrm{WaCraV1}$ is likely an invertebrate-infecting virus derived from insect RNA that

542 was eventually co-purified with the targeted plant RNA. The identification of invertebrate-infecting

543 viruses from plant transcriptome datasets was already reported elsewhere suggesting that some undetected

544 invertebrate was contaminating the plant samples [72]. Based on sequence similarities, the distinct

545 genomic organization and phylogenetic relationships WaCraV1, BeeMLV2 and BmMLV should be

546 classified as members of a novel genus within the Tymoviridae family, which could be tentatively named

547 as Inmaculavirus.

548 The KaV1 and PolWhV1 genome has three ORFs, 5'-Rep-P2-P3-3,' where ORFs 1 and 2 are separated

549 by a short intergenic region, while ORF3 is slightly overlapped with ORF2, which is likely a unique

550 genomic organization among tymoviruses. KaV1 and PolWhV1 replicases are distantly related with other

551 unclassified tymoviruses and mycotymoviruses, respectively, and the nt sequence similarity of its nearly

552 complete genome is below the $80 \%$ threshold value to demarcate species in the family Tymoviridae [21].

553 No hits were obtained when the proteins encoded by ORFs 2 and 3 of KaV1 and PolWhV1 were

554 analyzed, but a transmembrane domain was identified in the KaV1 encoded P2. Thus, KaV1 and

555 PolWhV1 P2 and P3 have an unknown function and is tempting to speculate that KaV1 P2 could have a

556 membrane associated function. Despite that Kav1 and PolWhV1 share a distinctive genomic organization

557 among tymoviruses, their evolutionary history is different because the KaV1 replicase virus formed a

558 monophyletic cluster that was distantly related with other tymoviruses, while PolWhV1 replicase

559 clustered together with mycotymoviruses. Thus, the evolutionary relationship of KaV1 with other known

560 members of the family Tymoviridae, and the unknown function of its putative P2 and P3 proteins suggest

561 that KaV1 likely represents a novel genus in the Tymoxiviridae family which could be tentatively as

562 Kavavirus. On the other hand, the evolutionary history of PolWhV1 suggest that this virus should be

563 classified as a novel member of the proposed genus Mycotymovirus [23], despite its genomic organization

564 is different than the reported mycotymoviruses [23, 73].

\section{Fungal RNA present in plant transcriptome datasets}

566 It is tempting to speculate that fungal RNA was also present in the Agave tequilana, Sesamum indicum

567 and Triticum polonicum transcriptomes given that the evolutionary analyses of ATV3, SesV1 and

568 PolWhV1 suggest they couldbe derived from a fungus associated to these plant samples. Furthermore, an

569 isolate of the fungi-associated deltaflexiviruses Erysiphe necator associated deltaflexivirus 2 and

570 Alternaria alternate deltaflexivirus 1 were identified in the transcriptome of Agrostis stolonifera 
571 (MW328744). Recently the putative gammaflexivirus pistacia-associated flexivirus 1 was identified

572

573

574

575

576

577

578

579

580

581

582

583

584

585

586

587

588

589

590

591

592

593

594

595

596

597

598

599

600

601

602

603

604

605

606

607

608

609

610

analysing a publically available transcriptome dataset of pistacia [39]. Thus, the identification of mycoviruses from plant transcriptome dataset its plausible and thus tentative host assignment should consider the potential impact of eventual mixed sampling of transcriptome datasets..

\section{Conclusion remarks}

In summary, this study shows the complexity and diversity of the genome organization of viruses belonging to the order Tymovirales and reveal that analyzing SRA public data is a valuable tool not only to speed up the identification of novel viruses but also to increase our understanding of their evolution and taxonomical classification. Nevertheless, our inability to go back to the biological material which was employed to generate the transcriptome datasets analyzed, in order to check the viral genome sequences assembled and link the virus to a specific host, is the main limitation of using the data mining as a tool for virus discovery. This constraint may lead to a potential misidentification of the host species linked to the virus. Therefore a cautious attitude must be carried out before making strong statements related to viruses discovered from the analysis of transcriptome datasets publically available. This study includes the identification and characterization of a diverse set of tymovirids, presenting striking genome organization flexibility and interesting phylogenetic cues which expands the evolutionary history of the order incorporating 31 new tentative members of species and genera within the order, highlighting the importance of HTS in virus discovery and its potential in virus taxonomy.

\section{Acknowledgments}

We would like to express a sincere gratitude to the generators of the underlying data used for this work, which are cited in Table 1. By following open access practices and supporting accessible raw sequence data in public repositories available to the research community, they have promoted the generation of new knowledge and ideas.

\section{References}

\section{References}

1. Gilbert KB, Holcomb EE, Allscheid RL, Carrington JC (2019) Hiding in plain sight: new virus genomes discovered via a systematic analysis of fungal public transcriptomes. PLoS One 14:e0219207.

2. Dolja VV, Krupovic M, Koonin EV (2020) Deep roots and splendid boughs of the global plant virome. Annu. Rev. Phytopathol. 58:23-53.

3. Lefeuvre P, Martin D, Elena SF, Shepherd DN, Roumagnac P, Varsani A (2019) Evolution and ecology of plant viruses. Nat. Rev. Microbiol. 17:632-644.

4. Roossinck MJ, Martin D, Roumagnac P (2015) Plant virus metagenomics: advances in virus discovery. Phytopathol. 105:716-727.

5. Koonin EV, Dolja VV, Krupovic M, Varsani A, Wolf YI, Yutin N, et al. (2020) Global Organization and Proposed Megataxonomy of the Virus World. Microbiol Mol Biol Rev. 84:133. 
611

6. Bejerman N, Roumagnac P, Nemchinov L. (2020) High-Throughput Sequencing for Deciphering the Virome of Alfalfa (Medicago sativa L.). Front Microbiol. 11:553109.

7. Debat HJ Bejerman N (2019) Novel bird's-foot trefoil RNA viruses provide insights into a clade of legume-associated enamoviruses and rhabdoviruses. Arch Virol. 164:1419-1426.

8. Goh C, Park D, Hahn Y (2020) Identification of Trichosanthes associated rhabdovirus 1, a novel member of the genus Cytorhabdovirus of the family Rhabdoviridae, in the Trichosanthes kirilowii transcriptome. Acta Virol. 64:36-43.

9. Jiang P, Shao J, Nemchinov LG (2019) Identification of emerging viral genomes in transcriptomic datasets of alfalfa (Medicago sativa L.). Virol J. 16:153.

10. Kim H, Park D, Hahn Y (2018). Identification a novel RNA viruses in alfalfa (Medicago sativa): an Alphapartitivirus, Deltapartitivirus, and a Marafivirus. Gene. 638:7-12.

11. Lauber C, Seifert M, Bartenschlager R, Seitz S. (2019) Discovery of highly divergent lineages of plant-associated astro-like viruses sheds light on the emergence of potyviruses. Virus Res. 260:38-48.

12. Nibert ML, Vong M, Fugate KK, Debat, HJ (2018) Evidence for contemporary plant mitoviruses. Virology 518:14-24.

13. Sidharthan K, Baranwal V (2021). Mining of water hyssop (Bacopa monnieri) transcriptome revealed the genome sequences of two putative novel rhabdoviruses and a solendovirus. Arch. Virol. 166:1985-1990.

14. Simmonds P, Adams MJ, Benko M, Breitbart M, Brister JR, Carstens EB, et al. (2017) Consensus statement: virus taxonomy in the age of metagenomics. Nat. Rev. Microbiol. 15:161168.

15. Adams MJ, Candresse T, Hammond J, Kreuze JF, Martelli GP, et al. (2012). Family Betaflexiviridae. In: King AMQ, Adams MJ, Carstens EB, Lefkowitz EJ (eds). Virus taxonomy. Ninth report of the International Committee on Taxonomy of Viruses. Elsevier Academic Press, London, pp 920-941.

16. Kreuze JF, Vaira AM, Menzel W, Candresse T, Zavriev SK, et al. (2020). ICTV virus taxonomy profile: Alphaflexiviridae. J GenVirol. 101:699.

17. International Committee on Taxonomy of Viruses (ICTV). (2020). Proposal 2020.031P Abolish the genus Mandarivirus, create one new subgenus (Mandarivirus) in the genus Potexvirus and one new subgenus (Acarillexivirus) in the genus Allexivirus (Tymovirales: Alphaflexiviridae). Retrieved $20^{\text {th }}$ April from https://talk.ictvonline.org.

18. Chen X, He H, Yang X, Zeng H, Qiu D, Guo L (2016) The complete genome sequence of a novel Fusarium graminearum RNA virus in a new proposed family within the order Tymovirales. Arch. Virol. 161:2899-2903.

19. Li K, Zheng D, Cheng J, Chen T, Fu Y, Jiang D, Xie J (2016) Characterization of a novel Sclerotinia sclerotiorum RNA virus as the prototype of a new proposed family within the order Tymovirales. Virus Res. 219:92-99. 
20. Rizwan Hamid MR, Xie J, Wu S, Maria SK, Zheng D, Assane HA, et al. (2018) A novel deltaflexivirus that infects the plant fungal pathogen, Sclerotinia sclerotiorum, can be transmitted among host vegetative incompatible strains. Viruses 10:E295.

21. Dreher TW, Edwards MC, Gibbs AJ, Haenni AL, Hammond RW, et al. (2012) Tymovirus. In: King AMQ, Adams MJ, Carstens EB, Lefkowitz EJ, editors. Virus taxonomy. Ninth report of the International Committee on Taxonomy of Viruses. Elsevier Academic Press, London, pp 946-952.

22. de Miranda JR, Cornman RS, Evans JD, Semberg E, Haddad N, Neumann P, et al. (2015) Genome characterization, prevalence and distribution of a macula-like virus from Apis mellifera and Varroa destructor. Viruses 7:3586-3602.

23. Li P, Lin Y, Zhang H, Wang S, Qiu D, Guo, L (2016). Molecular characterization of a novel mycovirus of the family Tymoviridae isolated from the plant pathogenic fungus Fusarium graminearum. Virology 489:86-94.

24. Wang L, Lu X, Zhai Y, Fu S, Wang D, Rayner S, et al. (2012) Genomic characterization of a novel virus of the family Tymoviridae isolated from mosquitoes. PLoS ONE 7:e39845.

25. Kumar S, Stecher G, Li M, Knyaz C, Tamura K (2018) MEGA X: Molecular evolutionary genetics analysis across computing platforms. Mol. Biol. Evol. 35:1547-1549.

26. Martin DP, Varsani A, Roumagnac P, Botha G, Maslamoney S, et al. (2020) RDP5: A computer program for analysing recombination in, and removing signals of recombination from, nucleotide sequence datasets. Virus Evol. 7:veaa087.

27. Francois S, Antoine-Lorquin, A, Kulikowski M, Frayssinet M, Filloux D, Fernandez E, et al. (2021). Characterisation of the Viral Community Associated with the Alfalfa Weevil (Hypera postica) and Its Host Plant, Alfalfa (Medicago sativa). Viruses 13:791.

28. Li Z, Wang G, Zhao R, Zhang Z, Xia Z, Zhai J, Huang X (2020) Complete genome sequence of a novel capillovirus infecting Hevea brasiliensis in China. Arch Virol 165:249-252.

29. Luo Q, Hu S, Lin Q, Xu F, Peng J, et al. (2021) Complete genome sequence of a novel foveavirus isolated from Allium sativum L. in China. Arch Virol. 166:983-986.

30. Marais A, Faure C, Theil S, Candresse T (2018). Molecular characterization of a novel species of capillovirus from Japanese apricot (Prunus mume). Viruses 10:144.

31. Thekke-Veetil T, Ho T, Postman JD, Martin RR, Tzanetakis IE (2018). A virus in American Blackcurrant (Ribes americanum) with distinct genome features reshapes classification in the tymovirales. Viruses, 10:406.

32. Veerakone S, Liefting L, Khan S, Pal C, Tang J, Ward L (2021) Partial biological and molecular characterization of a novel citrivirus from Nandina domestica. Arch Virol. 166:1395-1399.

33. Zheng L, Chen M, Li R (2020) Camellia ringspot-associated virus 4, a proposed new foveavirus from Camellia japonica. Arch Virol. 165:1707-1710.

34. Goh C, Park D, Kim H, Sebastiani F, Hahn Y (2018) Novel Divavirus (the family Betaflexiviridae) and Mitovirus (the family Narnaviridae) species identified in basil (Ocimum basilicum). Acta Virol. 62:304-309. 
35. Goh C, Park D, Lee J, Davey P, Pernice M, et al. (2019) Zostera virus T-a novel virus of the genus Tepovirus identified in the eelgrass, Zostera muelleri. Acta Virol. 63:366-372.

36. Goh C, Park D, Hahn Y (2021) A novel tepovirus, Agave virus T, identified by the analysis of the transcriptome data of blue agave (Agave tequilana). Acta Virol. 65:68-71.

37. Maachi A, Nagata T, Silva JMF (2020) Date palm virus A: first plant virus found in date palm trees. Virus Genes 56:792- 795 .

38. Park D, Zhang M, Hahn Y (2019) Novel Foveavirus (the family Betaflexiviridae) species identified in ginseng (Panax ginseng). Acta Virol. 63:155-161.

39. Park D, Goh C, Lee J, Sebastiani F, Hahn Y (2020). Identification of Pistacia-associated flexivirus 1, a putative mycovirus of the family Gammaflexiviridae, in the mastic tree (Pistacia lentiscus) transcriptome. Acta Virol. 64:28-35.

40. Sidharthan K, Kalaivanan N, Baranwal V (2021) Discovery of putative novel viruses in the transcriptomes of endangered plant species native to India and China. Gene. 786:145626.

41. Koonin EV, Dolja VV (1993) Evolution and taxonomy of positive-strand RNA viruses: implications of comparative analysis of amino acid sequences. Crit. Rev. Biochem. Mol. Biol. 28:375-430.

42. Linder P, Owttrim GW (2009) Plant RNA helicases: linking aberrant and silencing RNA. Trends Plant Sci 14:344-352.

43. Morozov SY, Solovyev AG (2020) Small hydrophobic viral proteins involved in intercellular movement of diverse plant virus genomes. Aims Microbiol. 6:305.

44. Morozov SY, Solovyev AG (2015) Phylogenetic relationship of some 'accessory' helicases of plant positive-stranded RNA viruses: toward understanding the evolution of triple gene block. Front Microbiol. 6:508.

45. Park MR, Jeong RD, Kim KH (2014) Understanding the intracellular trafficking and intercellular transport of potexviruses in their host plants. Front Plant Sci. 5:a60.

46. Rebelo AR, Niewiadomski S, Prosser SW, Krell P, Meng B (2008) Subcellular localization of the triple gene block proteins encoded by a Foveavirus infecting grapevines. Virus Res. 138:5769.

47. Wylie SJ, Li H, Jones MGK (2013) Donkey Orchid Symptomless Virus: A Viral 'Platypus’ from Australian Terrestrial Orchids. PLoS ONE 8:e79587.

48. Liu H, Wu L, Zheng L, Cao M, Li R (2019) Characterization of three new viruses of the family Betaflexiviridae associated with camellia ringspot disease. Virus Res. 272:197668.

49. Gao R, Li S, Lu M (2016) Complete nucleotide sequences of two isolates of Cherry virus A from sweet cherry in China. J Integr Agric 15:1667- 1671.

50. Jo Y, Choi H, Kim S-M, Kim S-L, Lee BC, Cho WK (2016) Integrated analyses using RNA-Seq data reveal viral genomes, single nucleotide variations, the phylogenetic relationship, and recombination for Apple stem grooving virus. BMC Genomics 17:579.

51. Roberts JM, Anderson DL, Durr PA (2018) Metagenomic analysis of Varroa-free Australian honey bees (Apis mellifera) shows a diverse Picornavirales virome. J. Gen. Virol. 99:818-826. 

characterization of grapevine Kizil Sapak virus, a novel grapevine-infecting member of the family Betaflexiviridae. Arch Virol 164:3145-3149.

53. Gattoni G, Minafra A, Castellano MA, De Stradis A, Boscia D, et al (2009) Some properties of Fig Latent Virus 1, a new member of the family Flexiviridae. J Plant Pathol 91:543-552. NGS-based full genome sequencing. PLoS ONE 11:e0146420.

55. Gambley CF, Thomas JE (2001) Molecular characterisation of Banana mild mosaic virus, a new filamentous virus in Musa spp. Arch. Virol. 146:1369-1379.

56. Thompson N, Randles JW (2001) The genome organisation and taxonomy of Sugarcane striate mosaic associated virus. Arch. Virol. 461:1441-1451.

57. Silva G, Bömer M, Rathnayake A, Sewe SO, Visendi P, Oyekanmi JO, et al. (2019) Molecular characterization of a new virus species identified in yam (Dioscorea spp.) by high-throughput sequencing. Plants 8:167.

58. Xuan Z, Li S, Zhang S, Ran W, Zhou Y, et al. (2020) Complete genome sequence of citrus yellow spot virus, a newly discovered member of the family Betaflexiviridae. Arch Virol. 165:2709-2713

59. Cao, M., Li, P., Zhang, S., Yang, F., Zhou, Y., et al (2018). Molecular characterization of a novel citrivirus from citrus using next-generation sequencing. Arch Virol 163:3479-3482

60. Da Silva LA, Oliveira AS, Melo FL, Ardisson-Araújo DMP, Resende FV, et al. (2019) A new virus found in garlic virus complex is a member of possible novel genus of the family Betaflexiviridae (order Tymovirales). Peer J 7:e6285.

61. Brewer E, Cao M, Gutierrez B, Bateman M, Li R (2020) Discovery and molecular characterization of a novel trichovirus infecting sweet cherry. Virus Genes. 56:380-385.

62. Zhou J, Zhang Z, Lu M, Xiao H, Habili N, Li S (2018) Complete nucleotide sequence of a new virus, peach chlorotic leaf spot virus, isolated from flat peach in China. Arch Virol 163:34593461.

63. Adams IP, Skelton A, Macarthur R, Hodges T, Hinds H, Flint L, et al. (2014) Carrot yellow leaf virus is associated with carrot internal necrosis. PLoS ONE 9:e109125.

64. Martelli GP, Adams MJ, Kreuze JF, Dolja VV (2007) Family Flexiviridae: A case study in virion and genome plasticity. Annu. Rev. Phytopathol. 45:73-100.

65. Nemchinov LG, François S, Roumagnac P, Ogliastro M, Hammond RW et al. (2018) Characterization of alfalfa virus F, a new member of the genus Marafivirus. PLoS ONE 13:e0203477.

66. Hou Q, Han T, Li L, Wang J, Yu M, Zhang S, Cao M, Yang C (2019) The complete nucleotide sequence and genome organization of a novel virus of the order tymovirales isolated from prunus davidiana (carr.) franch. in liaoning, china. Arch. Virol. 164:1245-1248.

67. Hily JM, Candresse T, Garcia S, Vigne E, Tannières M, Komar V, et al. (2018) Next-Generation Sequencing and the viromic study of grapevine leaves: from detection of grapevine-infecting viruses to description a new environmental Tymovirales. Front. Microbiol. 9:1782. 
68. Schoonvaere K, Smagghe G, Francis F, de Graaf DC (2018). Study of the metatranscriptome of eight social and solitary wild bee species reveals novel viruses and bee parasites. Front. Microbiol. 9:177.

69. Katsuma S, Tanaka S, Omuro N, Takabuchi L, Daimon, T, Imanishi S, et al. (2005) Novel macula-like virus identified in Bombyx mori cultured cells. J. Virol. 79, 5577-5584.

70. Elbeaino T, Digiaro M, Martelli GP (2011) Complete sequence of Fig fleck-associated virus, a novel member of the family Tymoviridae. Virus Res. 161, 198-202.

71. Martelli GP, Sabanadzovic S, Abou Ghanem-Sabanadzovic N, Saldarelli P (2002) Maculavirus, a new genus of plant viruses. Arch. Virol. 147:1847-1853.

72. Nery FMB, Melo FL, Boiteux LS, Ribeiro SG, Resende RO, et al (2020) Molecular characterization of Hovenia Dulcis-Associated Virus 1 (HDaV1) and 2 (HDaV2): new tentative species within the order Picornavirales. Viruses 12:950.

73. Wang Q, Cheng S, Xiao X, Cheng J, Fu Y, et al. (2019). Discovery of two mycoviruses by highthroughput sequencing and assembly of mycovirus-derived small silencing RNAs from a hypovirulent strain of Sclerotinia sclerotiorum. Front. Microbiol. 10:1415.

74. Malandrakis E, Dadali O, Kavouras M, Danis T, Panagiotaki P, et al. (2017) Identification of the abiotic stress-related transcription in little Neptune grass Cymodocea nodosa with RNAseq. Mar Genom. 34:47-56.

75. Zinkgraf M, Gerttula S, Groover A (2017) Transcript profiling of a novel plant meristem, the monocot cambium. J Integr Plant Biol. 59:436-449.

76. Hua W, Kong W, Cao XY, Chen C, Liu Q, Li X, Wang Z. (2017) Transcriptome analysis of Dioscorea zingiberensis identified genes involved in diosgenin biosynthesis. Genes \& Genomics 39:509-520.

77. Liu XF, Ma H, Li TQ, Li ZH, Wan YM, Liu XX, et al. (2018) Development of novel EST-SSR markers for Phyllanthus emblica (Phyllanthaceae) and cross-amplification in two related species. Appl Plant Sci. 6:e1169.

78. Amini H, Naghavi MR, Shen T, Wang Y, Nasiri J, et al. (2019) Tissue-specific transcriptome analysis reveals candidate genes for terpenoid and phenylpropanoid metabolism in the medicinal plant ferula assafoetida. G3. 9:807-16.

79. Gross SM, Martin JA, Simpson J, Abraham-Juarez MJ, Wang Z, Visel A (2013) De novo transcriptome assembly of drought tolerant CAM plants, Agave deserti and Agave tequilana. BMC Genomics 14:563.

80. Liquin L, Bo S, Deng WJ, Wang Y, Wei Y, et al. (2019) Avocado fruit pulp transcriptomes in the after-ripening process. Notulae Botanicae Horti Agrobotanici Cluj-Napoca. 47:308-319.

81. Ling LZ, Zhang S, Zhao F, Yang JL, Song WH, et al. (2017) Transcriptome-wide identification and prediction of miRNAs and their targets in Paris polyphylla var. yunnanensis by highthroughput sequencing analysis. Int J Mol Sci. 18: E219

82. Zhang L, Xu P, Cai Y, Ma L, Zhang C, Gao Q, et al. (2017) The draft genome assembly of Rhododendron delavayi Franch. var. delavayi. Gigascience 6: 1-11. 
83. Laricchia KM, Johnson MG, Ragone D, Williams EW, Zerega NJ, Wickett NJ (2018) A transcriptome screen for positive selection in domesticated breadfruit and its wild relatives (Artocarpus spp.). Am. J Bot 105:915-926.

84. Kavas M, Kizildogan AK, Balik HI (2019). Gene expression analysis of bud burst process in European hazelnut (Corylus avellana L.) using RNA-Seq. Physiol Mol Biol Pla. 25:13-29.

85. Fan ZP, Gao YK, Liu R, Wang XZ, Guo YC, Zhang QX (2020) The major gene and polygene effects of ornamental traits in bearded iris (Iris germanica) using joint segregation analysis Scientia Hort 260:108882.

86. Torrens-Spence MP, Pluskal T, Li FS, Carballo V, Weng JK (2018) Complete pathway elucidation and heterologous reconstitution of Rhodiola salidroside biosynthesis. Mol Plant 11:205-217.

87. Cegan R, Hudzieczek V, Hobza R (2017) De novo transcriptome assembly of heavy metal tolerant Silene dioica. Genomics Data 11:118-119.

88. Diray-Arce J, Clement M, Gul B, Khan AM, Nielsen BL (2015) Transcriptome assembly, profiling and differential gene expression analysis of the halophyte Suaeda fruticosa provides insights into salt tolerance. BMC Genomics 16:353.

89. Zhang S, Liu Q, Lyu C, Chen J, Xiao R, Chen J, Yang Y, Zhang H, Hou K, Wu W (2020) Characterizing glycosyltransferases by a combination of sequencing platforms applied to the leaf tissues of Stevia rebaudiana. BMC Genom 21:794

90. Feng G, Huang S, Liu Y, Xiao F, Liu J, et al. (2018) The transcriptome analyses of Tagetes erecta provides novel insights into secondary metabolite biosynthesis during flower development. Gene 660:18-27.

91. Piñeiro-Fernández L, Byers KJ, Cai J, Sedeek KE, Kellenberger RT, Russo A, et al. (2019) A phylogenomic analysis of the floral transcriptomes of sexually deceptive and rewarding European orchids, Ophrys and Gymnadenia. Front. Plant Sci. 10:1553.

92. Kado T, Innan H (2018) Horizontal gene transfer in five parasite plant species in Orobanchaceae. Genome Biol Evol 10:3196-3210.

93. Karinho-Betancourt E, Hernández-Soto P, Rendón-Anaya M, Calderón-Cortés N, Oyama K (2019) Differential expression of genes associated with phenolic compounds in galls of Quercus castanea induced by Amphibolips michoacaensis. J Plant Interact 14:177-186.

94. Zhang H, Wei L, Miao H, Zhang T, Wang C (2012) Development and validation of genic-SSR markers in sesame by RNA-seq. BMC Genomics 13:316.

95. Yang H, Zhou C, Li G, Wang J, Gao P et al (2019). RNA data from multiple tissues of Davidia involucrate. Sci Data. 6:181.

96. Voutsina N, Payne AC, Hancock RD, Clarkson GJJ, Rothwell SD (2016) Characterization of the watercress (Nasturtium officinale R. Br.; Brassicaceae) transcriptome using RNASeq and identification of candidate genes for important phytonutrient traits linked to human health. BMC Genom 17:378.

97. Pluskal T, Torrens-Spence MP, Fallon TR, De Abreu A, Shi CH, Weng J-K (2019) The biosynthetic origin of psychoactive kavalactones in kava. Nat. Plants 5:867-878. 
98. Wang Y, Wang X, Wang C, Wang R, Peng F, Xiao X, Zeng J, Fan X, Kang H, Sha L, Zhang H, Zhou Y (2016) Proteomic profiling of the interactions of $\mathrm{Cd} / \mathrm{Zn}$ in the roots of dwarf polish wheat (Triticum polonicum L.). Front Plant Sci 7:1378.

99. Zinkgraf M, Zhao S, Canning C, Gerttula S, Lu M, et al. (2020) Evolutionary network genomics of wood formation in a phylogenetic survey of angiosperm forest trees. New Phytol 228:1811-

\section{Ethics declaration}

854 Conflict of interest

855 The authors declare that they have no conflict of interest.

856 Human and animal rights statement

857 This manuscript presents original work that does not involve studies with humans or animals. 
Table 1. Summary of the tymovirids contigs identified from plant transcriptome data available in the NCBI database

\begin{tabular}{|c|c|c|c|c|c|c|c|c|c|c|c|}
\hline $\begin{array}{c}\text { Virus } \\
\text { family/genus }\end{array}$ & $\begin{array}{c}\text { Plant host; } \\
\text { monocot/dicot }\end{array}$ & Virus name & $\begin{array}{l}\text { Abbrevi- } \\
\text { ation }\end{array}$ & Bioproject ID & $\begin{array}{c}\text { Data } \\
\text { Citation }\end{array}$ & $\begin{array}{l}\text { Lenght } \\
\text { (nt) }\end{array}$ & $\begin{array}{c}\text { Accession } \\
\text { number }\end{array}$ & $\begin{array}{c}\text { ORF } \\
\text { (nt position) }\end{array}$ & Protein ID & $\begin{array}{l}\text { Lenght } \\
\text { (aa) }\end{array}$ & $\begin{array}{l}\text { Highest scoring virus- } \\
\text { protein } / E \text {-value/query } \\
\text { coverage \% (Blast P) }\end{array}$ \\
\hline $\begin{array}{l}\text { Iphaflexiviridael } \\
\text { unclassified }\end{array}$ & $\begin{array}{c}\text { Neptune grass } \\
(\text { Cymodocea } \\
\text { nodosa }) ; \text { monocot }\end{array}$ & $\begin{array}{c}\text { Cymodocea } \\
\text { nodosa virus } \\
1\end{array}$ & CyNoV1 & PRJNA275569 & [74] & 5508 & MW128740 & $\begin{array}{c}1(107-4438) \\
2(4480-5325)\end{array}$ & $\begin{array}{c}\text { Replicase } \\
\text { MP }\end{array}$ & $\begin{array}{c}1443 \\
281\end{array}$ & $\begin{array}{c}\text { DOSV-Rep/0.0/76 } \\
\text { DOSV-MP/2e-22/73 }\end{array}$ \\
\hline $\begin{array}{l}\text { Iphaflexiviridael } \\
\text { Potexvirus }\end{array}$ & $\begin{array}{l}\text { Spanish dagger } \\
(\text { Yucca gloriosa }) \\
\text { monocot }\end{array}$ & $\begin{array}{l}\text { Yucca } \\
\text { gloriosa } \\
\text { virus } 1\end{array}$ & YuGlV1 & PRJNA374584 & [75] & 6341 & MW328742 & $\begin{array}{c}1(109-4278) \\
2(4317-4988) \\
3(4975-5364) \\
4(5198-5437) \\
5(5440-6279) \\
\end{array}$ & $\begin{array}{l}\text { Replicase } \\
\text { TGB1 } \\
\text { TGB2 } \\
\text { TGB3 } \\
\text { CP } \\
\end{array}$ & $\begin{array}{c}1389 \\
223 \\
129 \\
79 \\
279 \\
\end{array}$ & $\begin{array}{c}\text { EuYMaV-Rep/0.0/98 } \\
\text { LVX-TGB1/2e-9/99 } \\
\text { YVX-TGB2/3e-8/73 } \\
\text { MaMV-TGB3/7e-09/ } \\
\text { EuYMaV-CP/1e-50/9 } \\
\end{array}$ \\
\hline $\begin{array}{l}\text { Iphaflexiviridael } \\
\text { Potexvirus }\end{array}$ & $\begin{array}{c}\text { Peltate yam } \\
\text { (Dioscorea } \\
\text { zingiberensis); } \\
\text { monocot }\end{array}$ & $\begin{array}{l}\text { Peltate yam } \\
\text { virus } 1\end{array}$ & PelYV1 & PRJNA243000 & [76] & 6253 & MW328724 & $\begin{array}{c}1(82-4232) \\
2(4232-4948) \\
3(4926-5255) \\
4(5125-5367) \\
5(5418-6119) \\
\end{array}$ & $\begin{array}{c}\text { Replicase } \\
\text { TGB1 } \\
\text { TGB2 } \\
\text { TGB3 } \\
\text { CP } \\
\end{array}$ & $\begin{array}{c}1382 \\
238 \\
109 \\
80 \\
233 \\
\end{array}$ & 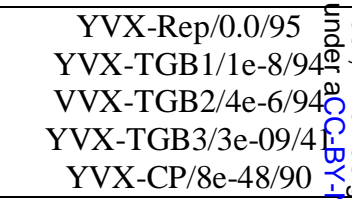 \\
\hline $\begin{array}{l}\text { Iphaflexiviridael } \\
\text { Potexvirus }\end{array}$ & $\begin{array}{c}\text { Indian gooseberry } \\
\text { (Phyllanthus } \\
\text { emblica }) ; \text { dicot }\end{array}$ & $\begin{array}{l}\text { Indian } \\
\text { gooseberry } \\
\text { virus } 1\end{array}$ & InGoV1 & PRJNA431341 & [77] & 6269 & MW328725 & $\begin{array}{c}1(66-4055) \\
2(4165-4890) \\
3(4865-5218) \\
4(5151-5351) \\
5(5357-6157) \\
\end{array}$ & $\begin{array}{l}\text { Replicase } \\
\text { TGB1 } \\
\text { TGB2 } \\
\text { TGB3 } \\
\text { CP } \\
\end{array}$ & $\begin{array}{c}1329 \\
241 \\
117 \\
66 \\
266 \\
\end{array}$ & $\begin{array}{l}\text { YVX-Rep/0.0/99\% } \\
\text { EuYMaV-TGB1/5e-41 } \\
\text { EuYMaV-TGB2/7e-24/\$ } \\
\text { YVX-TGB3/1e-07/8 } \\
\text { EuYMaV-CP/2e-60/8ळ }\end{array}$ \\
\hline $\begin{array}{l}\text { Iphaflexiviridael } \\
\text { Potexvirus }\end{array}$ & $\begin{array}{c}\text { Devil's dung } \\
\quad \text { (Ferula } \\
\text { assafoetida); dicot }\end{array}$ & $\begin{array}{c}\text { Ferula virus } \\
1\end{array}$ & FerV1 & PRJNA476150 & [78] & 5891 & MW328726 & $\begin{array}{l}1(129-4034) \\
2(4051-4749) \\
3(4727-5071) \\
4(4977-5198) \\
5(5146-5769) \\
\end{array}$ & $\begin{array}{l}\text { Replicase } \\
\text { TGB1 } \\
\text { TGB2 } \\
\text { TGB3 } \\
\text { CP } \\
\end{array}$ & $\begin{array}{c}1301 \\
232 \\
114 \\
73 \\
207 \\
\end{array}$ & 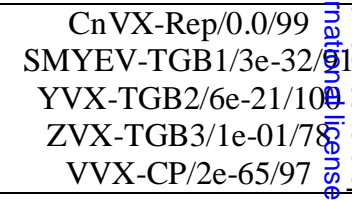 \\
\hline $\begin{array}{l}\text { Iphaflexiviridael } \\
\text { Potexvirus }\end{array}$ & $\begin{array}{l}\text { Blue agave } \\
\text { (Agave } \\
\text { tequilana); } \\
\text { monocot }\end{array}$ & $\begin{array}{l}\text { Agave } \\
\text { tequilana } \\
\text { virus } 2\end{array}$ & ATV2 & PRJNA193469 & [79] & 6555 & MW328740 & $\begin{array}{c}1(97-4440) \\
2(4474-5151) \\
3(5132-5521) \\
4(5328-5636) \\
5(5603-6433) \\
\end{array}$ & $\begin{array}{l}\text { Replicase } \\
\text { TGB1 } \\
\text { TGB2 } \\
\text { TGB3 } \\
\text { CP } \\
\end{array}$ & $\begin{array}{l}1447 \\
225 \\
129 \\
102 \\
276 \\
\end{array}$ & $\begin{array}{l}\text { VVX-Rep/0.0/98 } \\
\text { LVX-TGB1/5e-35/96 } \\
\text { YVX-TGB2/1e-18/72 } \\
\text { NMV-TGB3/1e-06/63 } \\
\text { EuYMaV-CP/5e-48/95 }\end{array}$ \\
\hline $\begin{array}{l}\text { Betaflexiviridael } \\
\text { unclassified }\end{array}$ & $\begin{array}{l}\text { Avocado (Persea } \\
\text { americana); dicot }\end{array}$ & $\begin{array}{l}\text { Avocado } \\
\text { virus } 2\end{array}$ & AvoV2 & PRJNA391003 & {$[80]$} & 8242 & MW328736 & $\begin{array}{c}1(82-6183) \\
2(6183-7490) \\
3(7126-7794) \\
\end{array}$ & $\begin{array}{c}\text { Replicase } \\
\text { MP } \\
\text { CP } \\
\end{array}$ & $\begin{array}{l}2033 \\
435 \\
222 \\
\end{array}$ & $\begin{array}{c}\text { CLBV-Rep/99/0.0 } \\
\text { CLBV-MP/4e-123/71 } \\
\text { CRSaV2-CP/2e-47/99 }\end{array}$ \\
\hline Betaflexiviridael & Neptune grass & Cymodocea & CyNoV2 & PRJNA275569 & [74] & $6292 *$ & MW328749 & $1(7-4248)$ & Replicase & $1415^{*}$ & GarYSaV-Rep/0.0/79 \\
\hline
\end{tabular}




\begin{tabular}{|c|c|c|c|c|c|c|c|c|c|c|c|}
\hline unclassified & $\begin{array}{c}\text { (Cymodocea } \\
\text { nodosa); monocot }\end{array}$ & $\begin{array}{c}\text { nodosa virus } \\
2\end{array}$ & & & & & & $\begin{array}{l}2(4273-4965) \\
3(4940-5269) \\
4(5205-5420) \\
5(5455-6120)\end{array}$ & $\begin{array}{c}\text { TGB1 } \\
\text { TGB2 } \\
\text { TGB3 } \\
\text { CP }\end{array}$ & $\begin{array}{c}230 \\
109 \\
71 \\
221 \\
\end{array}$ & $\begin{array}{c}\text { APV2-TGB1/3e-43/97 } \\
\text { PCMV-TGB2/2e-23/97 } \\
\text { ASPV-TGB3/3e-09/54 } \\
\text { GRSPaV/6e-52/83 }\end{array}$ \\
\hline $\begin{array}{l}\text { Betaflexiviridael } \\
\text { unclassified }\end{array}$ & $\begin{array}{c}\text { Dianchonglou } \\
\text { (Daiswa } \\
\text { yunannensis); } \\
\text { monocot }\end{array}$ & $\begin{array}{l}\text { Daiswa } \\
\text { yunannensis } \\
\text { virus 1 }\end{array}$ & DaYuV1 & PRJNA352766 & {$[81]$} & 6592 & MW328734 & $\begin{array}{c}1(44-5038) \\
2(4947-5909) \\
3(5947-6558)\end{array}$ & $\begin{array}{c}\text { Replicase } \\
\text { MP } \\
\text { CP }\end{array}$ & $\begin{array}{l}1663 \\
320 \\
203\end{array}$ & $\begin{array}{c}\text { MaBV-Rep/0.0/95 } \\
\text { MaTV1-MP/3e-94/83 } \\
\text { GINV-CP/7e-24/74 }\end{array}$ \\
\hline $\begin{array}{c}\text { Betaflexiviridael } \\
\text { unclassified }\end{array}$ & $\begin{array}{c}\text { Red } \\
\text { rhododendron } \\
\text { (Rhododendron } \\
\text { delavayi); dicot } \\
\end{array}$ & $\begin{array}{l}\text { Rhododendr } \\
\text { on delavayi } \\
\text { virus } 2\end{array}$ & RhoDeV2 & PRJNA358123 & [82] & 7763 & MW328735 & $\begin{array}{c}1(129-5747) \\
2(6115-6903) \\
3(6623-7201)\end{array}$ & $\begin{array}{c}\text { Replicase } \\
\text { P2 } \\
\text { P3 }\end{array}$ & $\begin{array}{l}1872 \\
262 \\
192\end{array}$ & $\begin{array}{c}\text { CMLV-Rep/0.0/81 } \\
\text { no hits } \\
\text { no hits }\end{array}$ \\
\hline $\begin{array}{c}\text { Betaflexiviridael } \\
\text { Capillovirus }\end{array}$ & $\begin{array}{l}\text { Breadfruit } \\
\text { (Artocarpus } \\
\text { artilis); dicot }\end{array}$ & $\begin{array}{c}\text { Breadfruit } \\
\text { virus } 1\end{array}$ & BreFV1 & PRJNA311339 & [83] & 6501 & MW328738 & $\begin{array}{c}1(42-6359) \\
2(4829-5785)\end{array}$ & $\begin{array}{l}\text { Replicase } \\
\text { CP } \\
\text { MP }\end{array}$ & $\begin{array}{l}1890 \\
215 \\
318\end{array}$ & $\begin{array}{c}\text { ASGV-polyprot/0.0/1/ } \\
\text { ASGV-MP/0.0/100 }\end{array}$ \\
\hline $\begin{array}{c}\text { Betaflexiviridael } \\
\text { Capillovirus }\end{array}$ & $\begin{array}{l}\text { Common hazel } \\
\quad \text { (Corylus } \\
\text { Avellana); dicot }\end{array}$ & $\begin{array}{c}\text { Corylus } \\
\text { avellana } \\
\text { virus } 1\end{array}$ & CorAvV1 & PRJNA316492 & [84] & 6430 & MW328729 & $\begin{array}{c}1(21-6305) \\
2(4712-5707)\end{array}$ & $\begin{array}{c}\text { Replicase } \\
\text { CP } \\
\text { MP }\end{array}$ & $\begin{array}{c}1926 \\
168 \\
331\end{array}$ & ASGV-polyprot/0.0/10 \\
\hline $\begin{array}{c}\text { Betaflexiviridael } \\
\text { Capillovirus }\end{array}$ & $\begin{array}{l}\text { German iris (Iris } \\
\text { germanica); } \\
\text { monocot }\end{array}$ & $\begin{array}{l}\text { German iris } \\
\text { virus } 1\end{array}$ & GerIV1 & PRJNA638517 & [85] & $5286^{*}$ & MW328757 & $\begin{array}{c}1(1-5178) \\
2(3402-4523)\end{array}$ & $\begin{array}{c}\text { Replicase } \\
\text { CP } \\
\text { MP }\end{array}$ & $\begin{array}{c}1556^{*} \\
169 \\
373\end{array}$ & $\begin{array}{l}\text { ASGV-polyprot/0.0/9 } \\
\text { YVA-MP/2e-112/87 }\end{array}$ \\
\hline $\begin{array}{c}\text { Betaflexiviridael } \\
\text { Capillovirus }\end{array}$ & $\begin{array}{c}\text { Roseroot } \\
\text { (Rhodiola rosea) } \\
\text { dicot }\end{array}$ & $\begin{array}{c}\text { Rhodiola } \\
\text { rosea } \text { virus } 1\end{array}$ & RhRoV1 & PRJNA398393 & [86] & 6260 & MW328730 & $\begin{array}{c}1(45-6194) \\
2(4676-5920) \\
\end{array}$ & $\begin{array}{c}\text { Replicase } \\
\text { CP } \\
\text { MP }\end{array}$ & $\begin{array}{l}1887 \\
162 \\
414 \\
\end{array}$ & 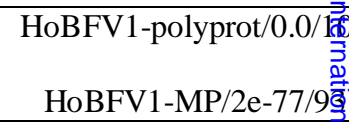 \\
\hline $\begin{array}{c}\text { Betaflexiviridael } \\
\text { Capillovirus }\end{array}$ & $\begin{array}{c}\text { Red campion } \\
\text { (Silene dioica); } \\
\text { dicot }\end{array}$ & $\begin{array}{l}\text { Silene dioica } \\
\quad \text { virus } 1\end{array}$ & SiDiV1 & PRJNA356362 & [87] & 7035 & MW328728 & $\begin{array}{c}1(62-6841) \\
2(5242-6336) \\
\end{array}$ & $\begin{array}{c}\text { Replicase } \\
\text { CP } \\
\text { MP } \\
\end{array}$ & $\begin{array}{c}2068 \\
191 \\
364 \\
\end{array}$ & 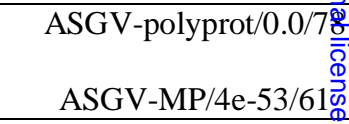 \\
\hline $\begin{array}{c}\text { Betaflexiviridael } \\
\text { Capillovirus }\end{array}$ & $\begin{array}{l}\text { Shrubby seablite } \\
\text { (Suaeda } \\
\text { fruticosa); dicot }\end{array}$ & $\begin{array}{c}\text { Suaeda } \\
\text { fruticosa } \\
\text { virus } 1 \\
\end{array}$ & SuFruV1 & PRJNA279892 & [88] & 6639 & MW328748 & $\begin{array}{c}1(1-6639) \\
2(5043-6299) \\
\end{array}$ & $\begin{array}{c}\text { Replicase } \\
\text { CP } \\
\text { MP }\end{array}$ & $\begin{array}{c}2050 \\
162 \\
418 \\
\end{array}$ & $\begin{array}{l}\text { CRSaV3-polyprot/0.0/9 } \\
\text { CRSaV3-MP/5e-123/88 }\end{array}$ \\
\hline $\begin{array}{c}\text { Betaflexiviridael } \\
\text { Carlavirus }\end{array}$ & $\begin{array}{l}\text { Sweetleaf (Stevia } \\
\text { rebaudiana); } \\
\text { dicot }\end{array}$ & $\begin{array}{l}\text { Sweetleaf } \\
\text { virus } 1\end{array}$ & SLeV1 & PRJNA591974 & [89] & 8477 & MW328722 & $\begin{array}{c}1(46-5919) \\
2(5950-6645) \\
3(6623-6949) \\
4(6942-7127) \\
5(7176-8066) \\
6(8063-8401)\end{array}$ & $\begin{array}{c}\text { Replicase } \\
\text { TGB1 } \\
\text { TGB2 } \\
\text { TGB3 } \\
\text { CP } \\
\text { NABP }\end{array}$ & $\begin{array}{c}1957 \\
231 \\
108 \\
61 \\
296 \\
112 \\
\end{array}$ & $\begin{array}{c}\text { HelVS-Rep/0.0/100 } \\
\text { HelVS-TGB1/4e-99/10 } \\
\text { GLV-TGB2/1e-42/100 } \\
\text { GLV-TGB3/4e-09/78 } \\
\text { HelVS/CP/3e-135/100 } \\
\text { GLV-NABP/2e-42/94 } \\
\end{array}$ \\
\hline
\end{tabular}




\begin{tabular}{|c|c|c|c|c|c|c|c|c|c|c|c|}
\hline $\begin{array}{l}\text { Betaflexiviridael } \\
\text { Carlavirus }\end{array}$ & $\begin{array}{c}\text { African marigold } \\
\text { (Tagetes erecta); } \\
\text { dicot }\end{array}$ & $\begin{array}{c}\text { Tagetes } \\
\text { erecta virus } \\
2\end{array}$ & TaEV2 & PRJNA431782 & [90] & 8499 & MW328723 & $\begin{array}{c}1(70-5952) \\
2(5984-6679) \\
3(6657-6986) \\
4(6976-7161) \\
5(7209-8096) \\
6(8093-8498) \\
\end{array}$ & $\begin{array}{c}\text { Replicase } \\
\text { TGB1 } \\
\text { TGB2 } \\
\text { TGB3 } \\
\text { CP } \\
\text { NABP } \\
\end{array}$ & $\begin{array}{c}1960 \\
231 \\
109 \\
61 \\
295 \\
111 \\
\end{array}$ & $\begin{array}{c}\text { HelVS-Rep/0.0/99 } \\
\text { HelVS-TGB1/6e-101/99 } \\
\text { PhlVS-TGB2/3e-41/99 } \\
\text { SLV-TGB3/7e-06/90 } \\
\text { HelVS-CP/1e-136/100 } \\
\text { GLV-NABP/1e-34/100 }\end{array}$ \\
\hline $\begin{array}{c}\text { Betaflexiviridael } \\
\text { Divavirus }\end{array}$ & $\begin{array}{l}\text { Dark vanilla } \\
\text { orchid } \\
\text { (Gymnadenia } \\
\text { rhellicani); } \\
\text { monocot }\end{array}$ & $\begin{array}{l}\text { Gymnadenia } \\
\text { rhellicani } \\
\text { virus } 1\end{array}$ & GymRhV1 & PRJNA504609 & [91] & 7490 & MW328732 & $\begin{array}{l}1(104-6814) \\
2(5170-6291) \\
3(6834-7268)\end{array}$ & $\begin{array}{c}\text { Replicase } \\
\text { CP } \\
\text { MP } \\
\text { NABP }\end{array}$ & $\begin{array}{c}2084 \\
167 \\
373 \\
144\end{array}$ & $\begin{array}{l}\text { DiVB-polyprot/0.0/93 } \\
\text { ObRV1-MP/9e-66/80 } \\
\text { CMLV-P4/3e-04/46 }\end{array}$ \\
\hline $\begin{array}{c}\text { Betaflexiviridael } \\
\text { Divavirus }\end{array}$ & $\begin{array}{l}\text { Korean chestnut } \\
\quad \text { (Castanea } \\
\text { crenata); dicot }\end{array}$ & $\begin{array}{l}\text { Korean } \\
\text { chestnut } \\
\text { virus } 1\end{array}$ & KoChV1 & PRJNA534190 & $\begin{array}{c}\text { Park, E.J., } \\
\text { South } \\
\text { Korea; } \\
\text { unpublished } \\
\end{array}$ & 7348 & MW328731 & $\begin{array}{c}1(45-7040) \\
2(5285-6484)\end{array}$ & $\begin{array}{c}\text { Replicase } \\
\text { CP } \\
\text { MP }\end{array}$ & $\begin{array}{c}2160 \\
171 \\
399\end{array}$ & 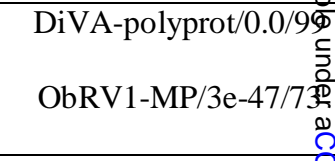 \\
\hline $\begin{array}{c}\text { Betaflexiviridael } \\
\text { Divavirus }\end{array}$ & $\begin{array}{l}\text { Asian cow-wheat } \\
\text { (Melampyrum } \\
\text { roseum); dicot }\end{array}$ & $\begin{array}{l}\text { Melampyru } \\
\text { m roseum } \\
\text { virus } 2\end{array}$ & MelRoV2 & PRJDB5395 & [92] & 7094 & MW328733 & $\begin{array}{c}1(50-6403) \\
2(4723-5826) \\
3(6426-6911) \\
\end{array}$ & $\begin{array}{c}\text { Replicase } \\
\text { CP } \\
\text { MP } \\
\text { NABP }\end{array}$ & $\begin{array}{c}1954 \\
163 \\
367 \\
161 \\
\end{array}$ & $\begin{array}{l}\text { DiVB-polyprot/0.0/9 } \\
\text { DiVA-MP/3e-63/84 } \\
\text { CMLV-P4/6e-04/41 }\end{array}$ \\
\hline $\begin{array}{c}\text { Betaflexiviridael } \\
\text { Divavirus }\end{array}$ & $\begin{array}{l}\text { Capulincillo oak } \\
\text { (Quercus } \\
\text { castanea); dicot }\end{array}$ & $\begin{array}{c}\text { Quercus } \\
\text { castanea } \\
\text { virus 1 }\end{array}$ & QueCaV1 & PRJNA532454 & [93] & 7761 & MW328737 & $\begin{array}{c}1(30-7025) \\
2(5282-6469)\end{array}$ & $\begin{array}{c}\text { Replicase } \\
\text { CP } \\
\text { MP }\end{array}$ & $\begin{array}{c}2150 \\
181 \\
395\end{array}$ & $\begin{array}{l}\text { DiVA-polyprot/0.0/10日 } \\
\text { DiVA-MP/1e-42/67 }\end{array}$ \\
\hline $\begin{array}{l}\text { Betaflexiviridael } \\
\text { Fivivirus }\end{array}$ & $\begin{array}{l}\text { Avocado (Persea } \\
\text { americana); dicot }\end{array}$ & $\begin{array}{c}\text { Avocado } \\
\text { virus } 1\end{array}$ & AvoV1 & PRJNA391003 & [80] & 8002 & MW328739 & $\begin{array}{c}1(115-5499) \\
2(5560-6498) \\
3(6281-6922) \\
4(6997-7815) \\
5(7640-7978) \\
\end{array}$ & $\begin{array}{c}\text { Replicase } \\
\text { MP } \\
\text { CP } \\
\text { P4 } \\
\text { NABP } \\
\end{array}$ & $\begin{array}{l}1794 \\
312 \\
213 \\
272 \\
112 \\
\end{array}$ & $\begin{array}{c}\text { GKSV-Rep/0.0/90 } \\
\text { FLV1/2e-32/88 } \\
\text { FLV1/4e-4/88 } \\
\text { no hits } \\
\text { GKSV-NABP/0.009/8 } \\
\end{array}$ \\
\hline $\begin{array}{l}\text { Deltaflexiviridael } \\
\text { Deltaflexivirus }\end{array}$ & $\begin{array}{l}\text { Blue agave } \\
\text { (Agave } \\
\text { tequilana); } \\
\text { monocot }\end{array}$ & $\begin{array}{l}\text { Agave } \\
\text { tequilana } \\
\text { virus } 3\end{array}$ & ATV3 & PRJNA193469 & [79] & 8565 & MW328745 & $\begin{array}{c}1(13-6405) \\
2(6732-7043) \\
3(7126-7425) \\
4(7427-7951) \\
5(7945-8487)\end{array}$ & $\begin{array}{c}\text { Replicase } \\
\text { P2 } \\
\text { P3 } \\
\text { P4 } \\
\text { P5 } \\
\end{array}$ & $\begin{array}{c}2130 \\
103 \\
99 \\
174 \\
180 \\
\end{array}$ & $\begin{array}{c}\text { FgDFV1-Rep/0.0/97 } \\
\text { no hits } \\
\text { no hits } \\
\text { no hits } \\
\text { no hits }\end{array}$ \\
\hline $\begin{array}{l}\text { eltaflexiviridael } \\
\text { Deltaflexivirus }\end{array}$ & $\begin{array}{l}\text { Sesame (Sesamum } \\
\text { indicum); dicot }\end{array}$ & $\begin{array}{l}\text { Sesame } \\
\text { virus } 1\end{array}$ & SesV1 & PRNJA74261 & [94] & 8362 & MW328747 & $\begin{array}{c}1(54-6350) \\
2(6535-6732) \\
3(6803-7099) \\
4(7276-7788) \\
\end{array}$ & $\begin{array}{c}\text { Replicase } \\
\text { P2 } \\
\text { P3 } \\
\text { P4 } \\
\end{array}$ & $\begin{array}{c}2098 \\
65 \\
98 \\
170 \\
\end{array}$ & $\begin{array}{c}\text { FgDFV1-Rep/0.0/99 } \\
\text { no hits } \\
\text { no hits } \\
\text { FgDFV1-P4/2e-28/100 }\end{array}$ \\
\hline
\end{tabular}




\begin{tabular}{|c|c|c|c|c|c|c|c|c|c|c|c|}
\hline & & & & & & & & $5(7772-8248)$ & P5 & 158 & FgDFV1-P5/1e-07/97 \\
\hline $\begin{array}{l}\text { Tymoviridael } \\
\text { Marafivirus }\end{array}$ & $\begin{array}{c}\text { Dove-tree } \\
\text { (Davidia } \\
\text { involucrata); } \\
\text { dicot }\end{array}$ & $\begin{array}{l}\text { Davidia } \\
\text { involucrata } \\
\text { virus } 1\end{array}$ & DaInvV1 & PRJNA513477 & {$[95]$} & 7109 & MW328750 & $1(164-6955)$ & $\begin{array}{c}\text { Replicase } \\
\text { CP }\end{array}$ & $\begin{array}{c}2073 \\
190\end{array}$ & MsMV1-polyprot/0.0/9. \\
\hline $\begin{array}{l}\text { Tymoviridael } \\
\text { Maculavirus }\end{array}$ & $\begin{array}{c}\text { Watercress } \\
\text { (Nasturtium } \\
\text { officinale); dicot }\end{array}$ & $\begin{array}{l}\text { Watercress } \\
\text { associated } \\
\text { virus } 1\end{array}$ & WaCraV1 & PRJNA284126 & [96] & 6744 & MW328754 & $\begin{array}{c}1(253-5637) \\
2(5505-6317) \\
3(6229-6648)\end{array}$ & $\begin{array}{l}\text { Replicase } \\
\text { CP } \\
\text { P3 }\end{array}$ & $\begin{array}{l}1794 \\
270 \\
139\end{array}$ & $\begin{array}{l}\text { BmMLV-Rep/0.0/99) } \\
\text { BmMLV-CP/5e-49/8 } \\
\text { BmMLV-P3 /6e-13/6\$ }\end{array}$ \\
\hline $\begin{array}{l}\text { Tymoviridael } \\
\text { unclassified }\end{array}$ & $\begin{array}{c}\text { Kava (Piper } \\
\text { methysticum), } \\
\text { dicot }\end{array}$ & Kava virus 1 & KaV1 & PRJNA494686 & [97] & 9491 & MW328755 & $\begin{array}{c}1(218-7048) \\
2(7121-8215) \\
3(8016-9395)\end{array}$ & $\begin{array}{c}\text { Replicase } \\
\text { P2 } \\
\text { P3 }\end{array}$ & $\begin{array}{c}2276 \\
364 \\
459\end{array}$ & $\begin{array}{c}\text { UTyV1-Rep/3e-62/4 } \\
\text { no hits } \\
\text { no hits }\end{array}$ \\
\hline $\begin{array}{l}\text { Tymoviridael } \\
\text { unclassified }\end{array}$ & $\begin{array}{l}\text { Polish wheat } \\
\text { (Triticum } \\
\text { polonicum); } \\
\text { monocot }\end{array}$ & $\begin{array}{l}\text { Polish wheat } \\
\text { virus } 1\end{array}$ & PolWhV1 & PRJNA304266 & {$[98]$} & 7702 & MW328751 & $\begin{array}{c}1(99-6752) \\
2(6756-7148) \\
3(7093-7644)\end{array}$ & $\begin{array}{c}\text { Replicase } \\
\text { P2 } \\
\text { P3 }\end{array}$ & $\begin{array}{r}2217 \\
130 \\
183\end{array}$ & $\begin{array}{l}\text { FgMTV1-Rep/0.0/75 } \\
\text { no hits } \\
\text { no hits }\end{array}$ \\
\hline $\begin{array}{l}\text { Unassigned } \\
\text { /Gratylivirus }\end{array}$ & $\begin{array}{l}\text { Yellow poplar } \\
\text { (Liriodendron } \\
\text { tulipifera); dicot }\end{array}$ & $\begin{array}{c}\text { yellow } \\
\text { poplar virus } \\
1\end{array}$ & YePoV1 & PRJNA556244 & [99] & 6069 & MW328760 & $\begin{array}{c}1(35-5443) \\
2(5515-6057)\end{array}$ & $\begin{array}{c}\text { Replicase } \\
\text { CP }\end{array}$ & $\begin{array}{c}1802 \\
180\end{array}$ & $\begin{array}{l}\text { PYSaV-Rep/0.0/94 } \\
\text { PRSaV-CP/2e-50/98 }\end{array}$ \\
\hline & ial sequence & & & & & & & & & & 27 \\
\hline
\end{tabular}


bioRxiv preprint doi: https://doi.org/10.1101/2021.07.15.452586; this version posted July 16, 2021. The copyright holder for this preprint (which was not certified by peer review) is the author/funder, who has granted bioRxiv a license to display the preprint in perpetuity. It is made available under aCC-BY-NC-ND 4.0 International license.

Figure 1. Diagrams depicting the genomic organization of each (A) alphaflexivirus (B) betaflexivirus, (C) deltaflexivirus and (D) tymovirus sequence identified in this study. Abbreviations: MP, movement protein CDS; TGB1, triple gene block protein 1 CDS; TGB2, triple gene block protein 2 CDS; TGB3, triple gene block protein $3 \mathrm{CDS}$; $\mathrm{P}$ capsid protein CDS; NABP, nucleic acid binding protein CDS.

A

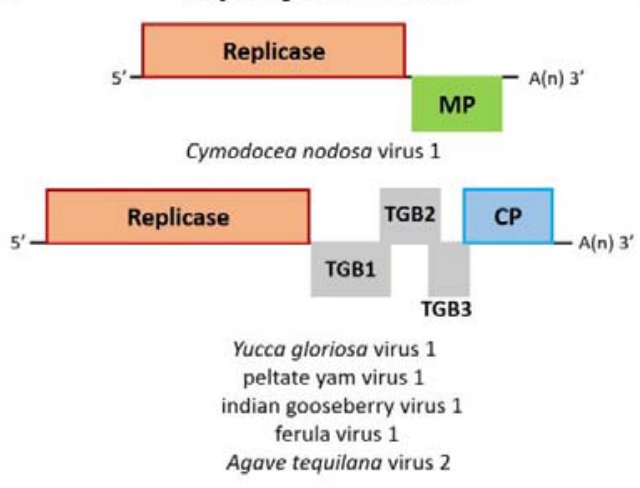

C

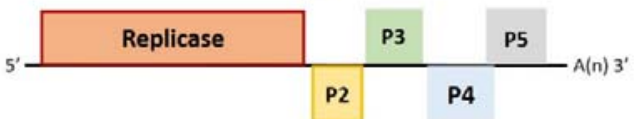

Agave tequilana virus 3 Sesame virus 1

\section{D}

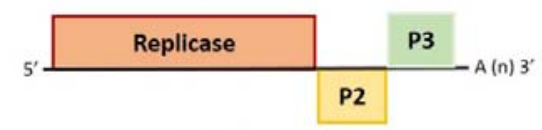

kava virus 1

polish wheat virus 1

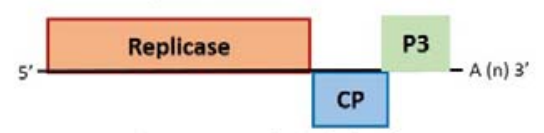

watercress associated virus 1

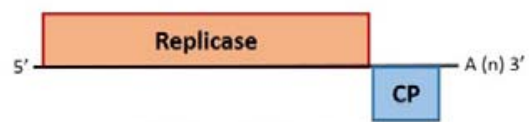

Yellow poplar virus 1

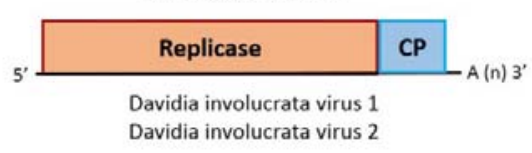

B Betaflexiviridae

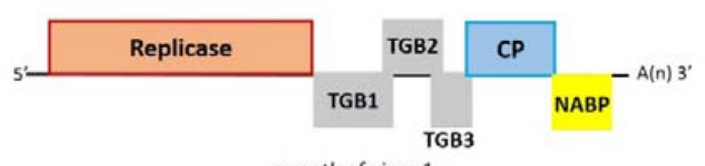

sweetleaf virus 1

Tagetes erecta virus 2

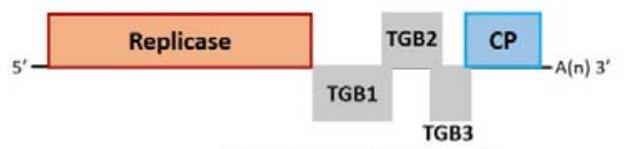

Cymodocea nodosa virus $2^{*}$

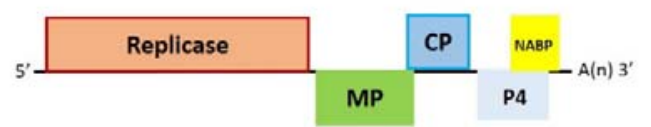

Avocado virus 1
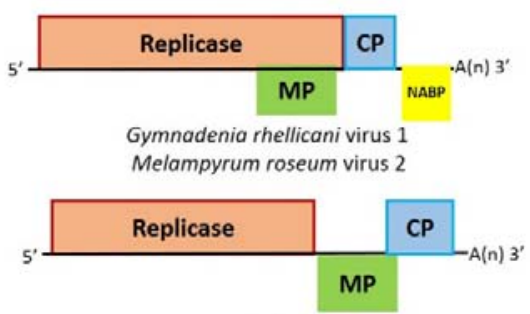

avocado virus 2
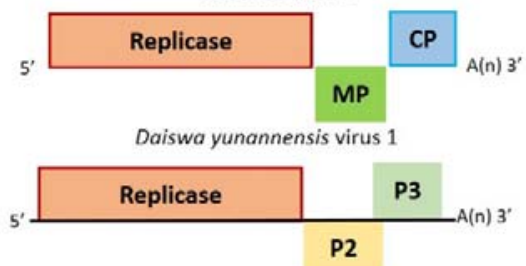

Rhododendron delavayi virus 2

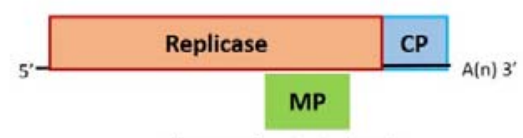

Korean chestnut virus 1

Quercus castanea virus 1 german iris virus $1^{*}$ Corylus avellana virus 1

breadfruit virus 1

Rhodiola rosea virus 1

Silene dioica virus 1

Suaeda fruticosa virus 1 
bioRxiv preprint doi: https://doi.org/10.1101/2021.07.15.452586; this version posted July 16, 2021. The copyright holder for this preprint (which was not certified by peer review) is the author/funder, who has granted bioRxiv a license to display the preprint in perpetuity. It is made available under aCC-BY-NC-ND 4.0 International license.

Figure 2. A Maximum Likelihood phylogenetic based on a multiple amino acid alignment of the replicase sequences of alphaflexiviruses, was constructed with the $\mathrm{WAG}+\mathrm{G}+\mathrm{F}$ model. Bootstrap values following 1000 replicates are given at the nodes, but only values above $40 \%$ are shown. Apple stem pitting virus, apricot latent virus, Helenium virus $\mathrm{S}$ and Chrysanthemum virus B replicase aa sequences were used as outgroup. The scale bar indicates the number of substitutions per site. Viruses identified in this study are noted with a green square. Accession numbers of every virus used to construct the ML tree are listed in Table S1.

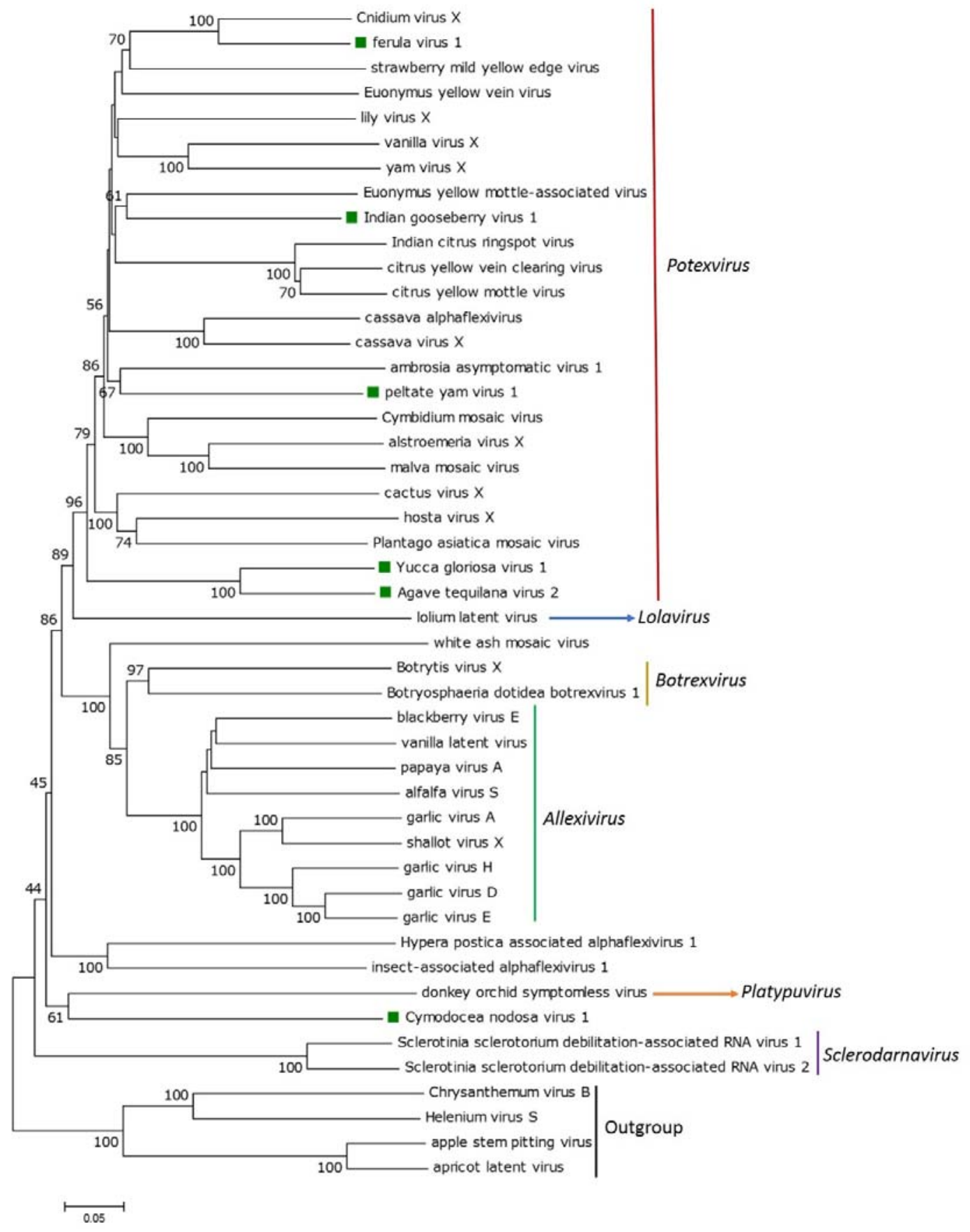


bioRxiv preprint doi: https://doi.org/10.1101/2021.07.15.452586; this version posted July 16, 2021. The copyright holder for this preprint (which was not certified by peer review) is the author/funder, who has granted bioRxiv a license to display the preprint in perpetuity. It is made available under aCC-BY-NC-ND 4.0 International license.

Figure 3. A Maximum Likelihood phylogenetic based on a multiple amino acid alignment of the replicases sequences of viruses of the subfamily Quinvirinae, was constructed with the $\mathrm{LG}+\mathrm{G}+\mathrm{F}$ model. Bootstrap values following 1000 replicates are given at the nodes, but only values above $40 \%$ are shown. Apricot pseudo-chlorotic leaf spot virus, cherry mottle leaf virus and Grapevine Berry Inner necrosis virus replicases aa sequences were used as outgroup. The scale bar indicates the number of substitutions per site. Viruses identified in this study are noted with a green square. Viruses identified with an * correspond to unpublished sequences derived from the analysis of RNA-Seq data publically available at the NCBI. Accession numbers of every virus used to construct the ML tree are listed in Table S1.

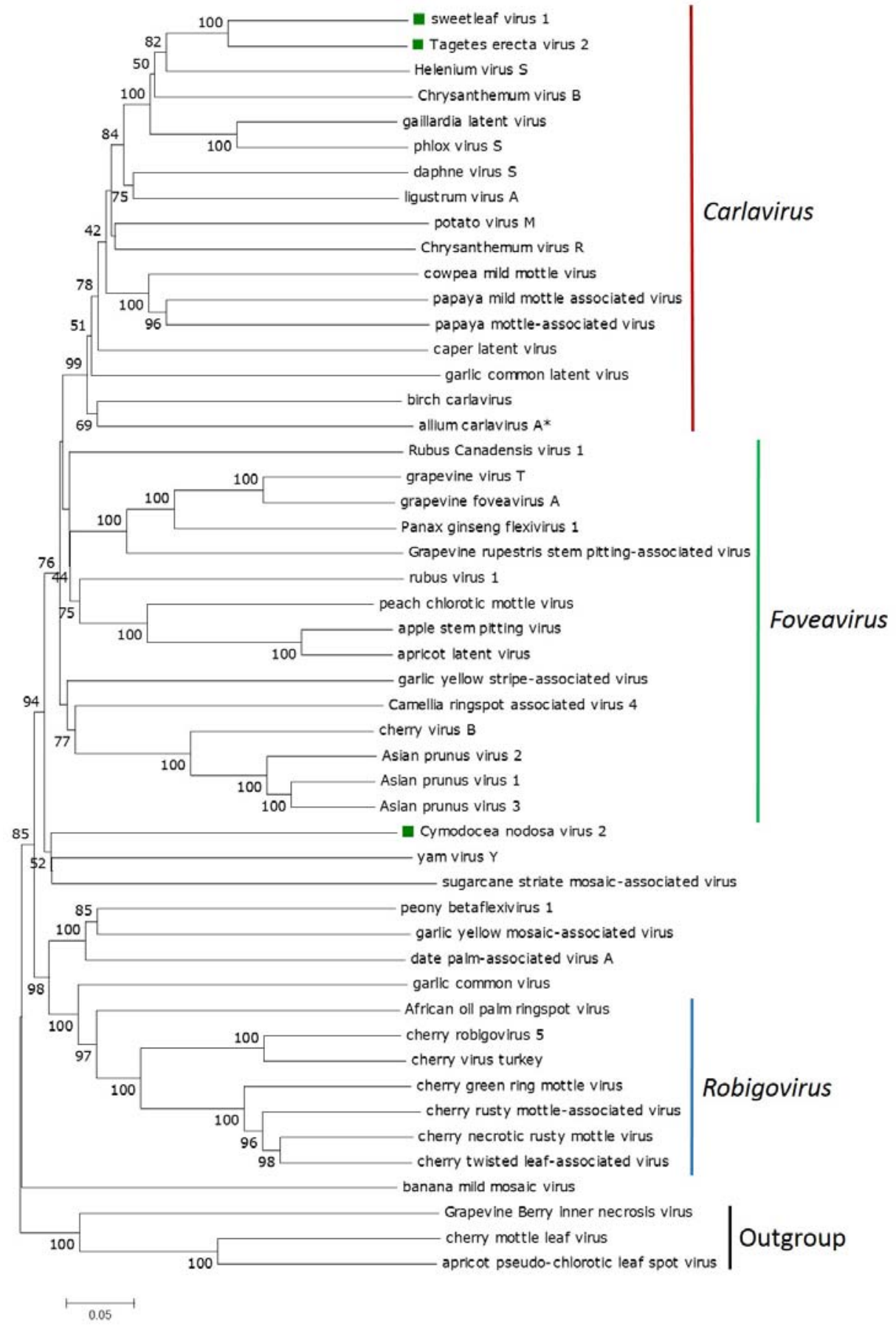


Figure 4. A Maximum Likelihood phylogenetic based on a multiple amino acid alignment of the replicases sequences of viruses of the subfamily Trinvirinae, was constructed with the $\mathrm{LG}+\mathrm{G}+\mathrm{F}$ model. Bootstrap values following 1000 replicates are given at the nodes, but only values above $40 \%$ are shown. Cnidium virus $X$, lily virus $X$ and vanilla virus $X$ replicases aa sequences were used as outgroup. The scale bar indicates the number of substitutions per site. Viruses identified in this study are noted with a green square. Viruses identified with an * correspond to unpublished sequences derived from the analysis of RNA-Seq data publically available at the NCBI. Accession numbers of every virus used to construct the ML tree are listed in Table S1.

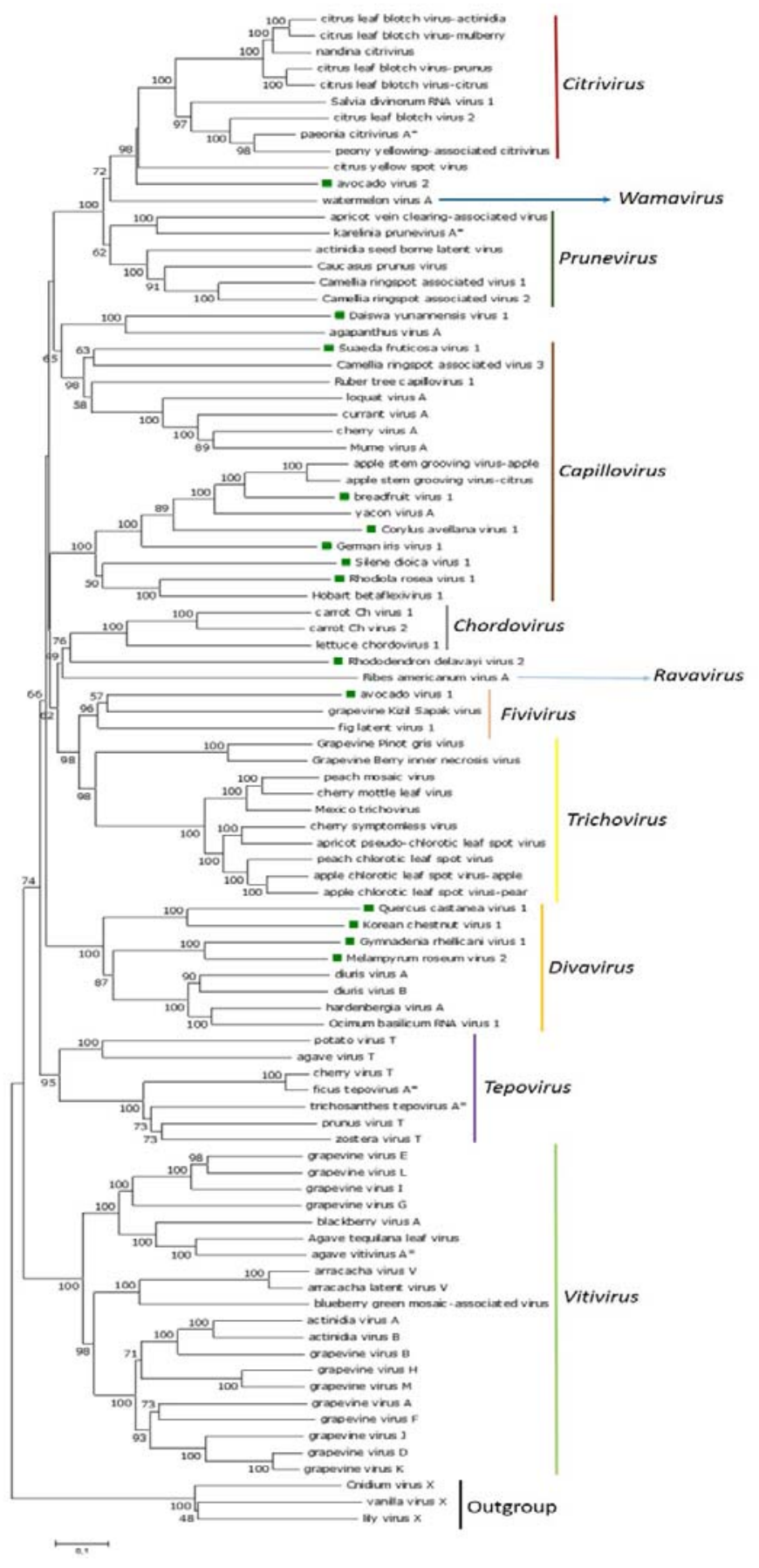


Figure 5. A Maximum Likelihood phylogenetic based on a multiple amino acid alignment of the replicase sequences of deltaflexiviruses, was constructed with the JTT $+\mathrm{G}$ model. Bootstrap values following 1000 replicates are given at the nodes, but only values above $40 \%$ are shown. The gammaflexiviruses Botrytis virus F, Entoleuca gammaflexivirus 1, Entoleuca gammaflexivirus 2 and pistacia-associated flexivirus 1 replicases aa sequences were used as outgroup. The scale bar indicates the number of substitutions per site. Viruses identified in this study are noted with a green square. Accession numbers of every virus used to construct the ML tree are listed in Table S1.

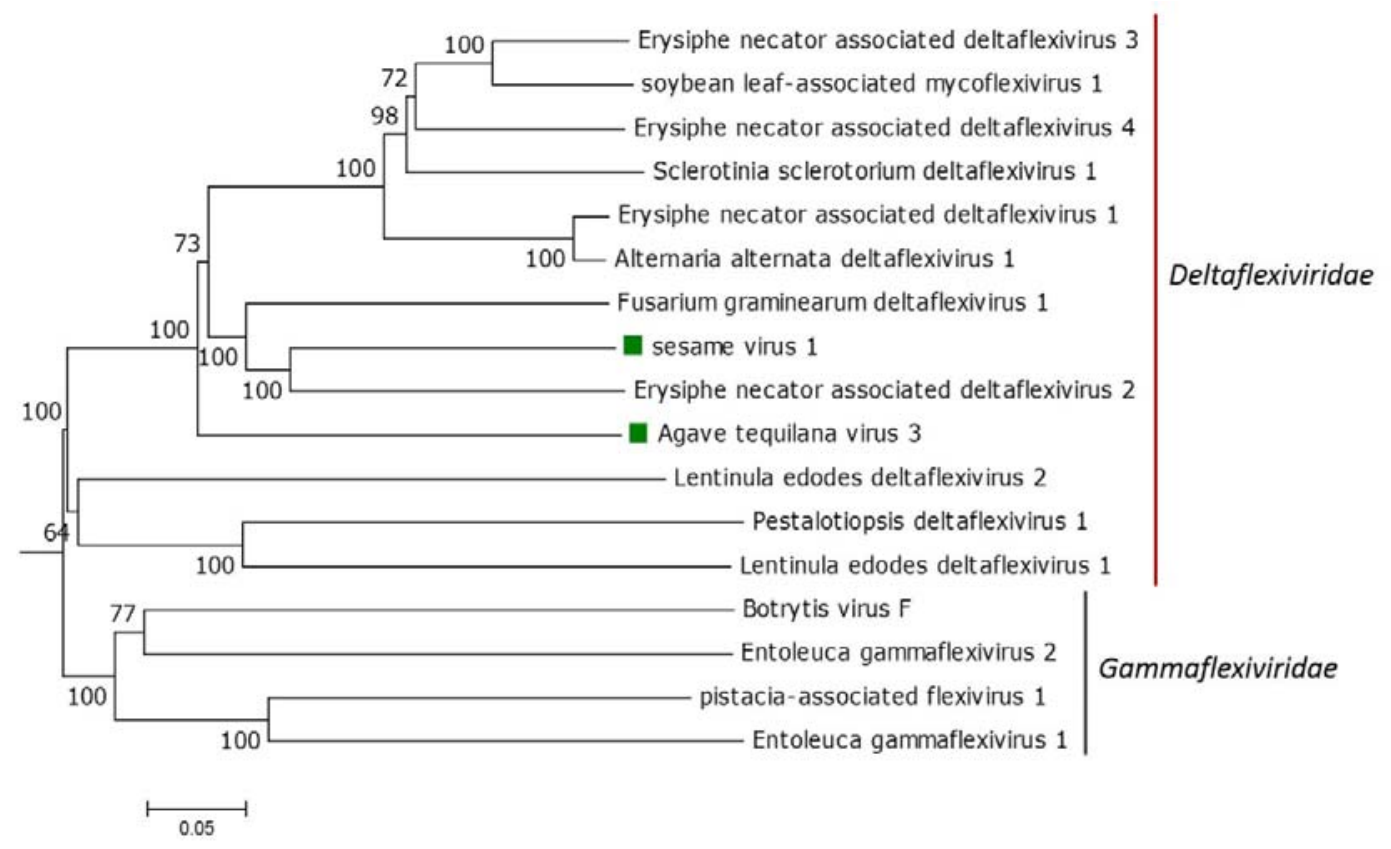


bioRxiv preprint doi: https://doi.org/10.1101/2021.07.15.452586; this version posted July 16, 2021. The copyright holder for this preprint (which was not certified by peer review) is the author/funder, who has granted bioRxiv a license to display the preprint in perpetuity. It is made available under aCC-BY-NC-ND 4.0 International license.

Figure 6. A Maximum Likelihood phylogenetic based on a multiple amino acid alignment of the replicase sequences of tymovirids, was constructed with the $\mathrm{WAG}+\mathrm{G}+\mathrm{F}$ model. Bootstrap values following 1000 replicates are given at the nodes, but only values above $40 \%$ are shown. . Apricot pseudochlorotic leaf spot virus, cherry mottle leaf virus and Grapevine Berry Inner necrosis virus replicases aa sequences were used as outgroup. The scale bar indicates the number of substitutions per site. Viruses identified in this study are noted with a green squares. Accession numbers of every virus used to construct the ML tree are listed in Table S1.

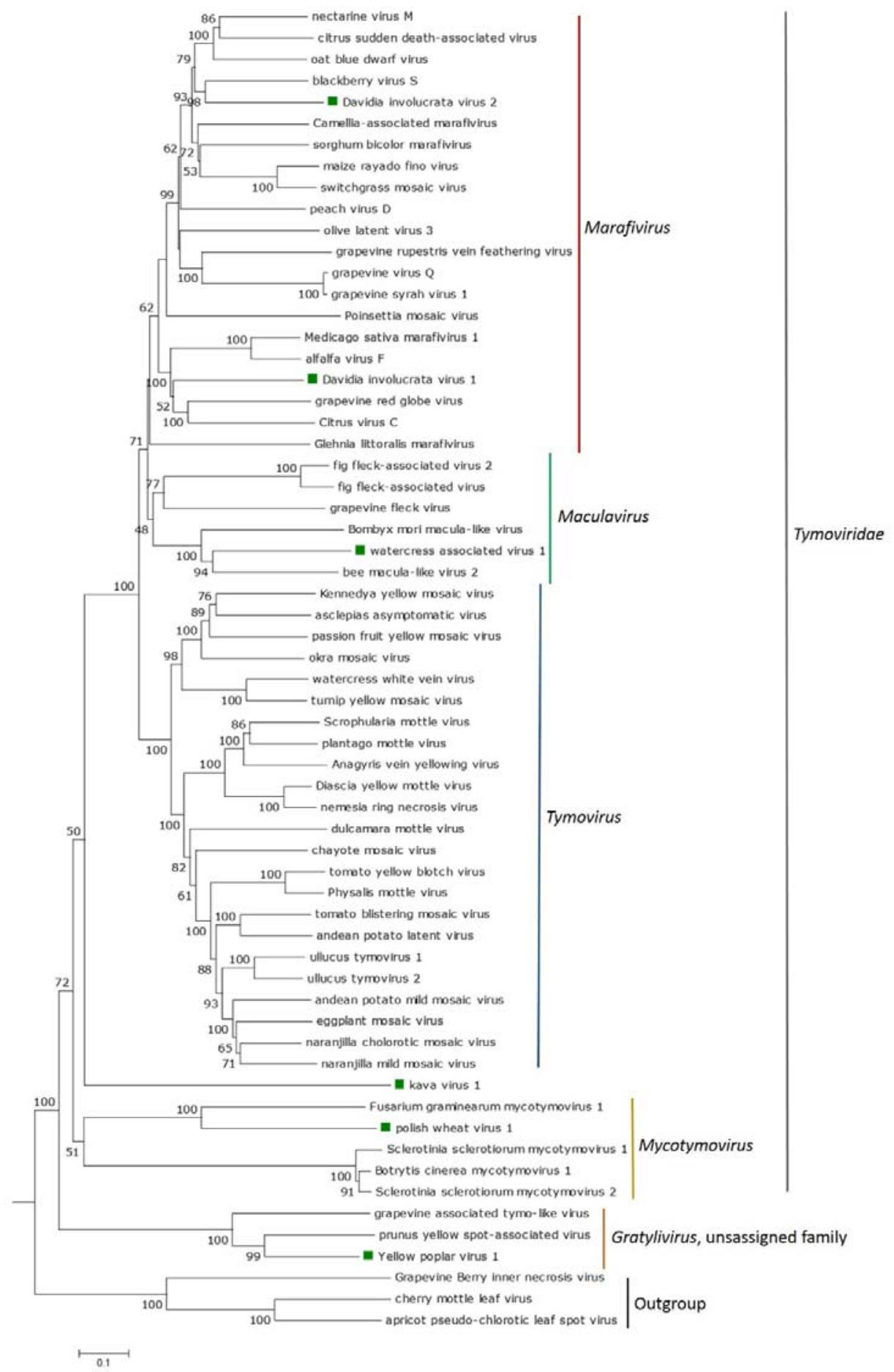

